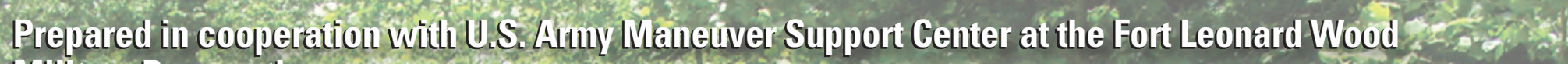
Wullitaly Reselvation

Aiydrologic and Sediment Data Collected From Selected Basilis at the Fort Leoliard Wood Military Reservation; Missouri-2010-11

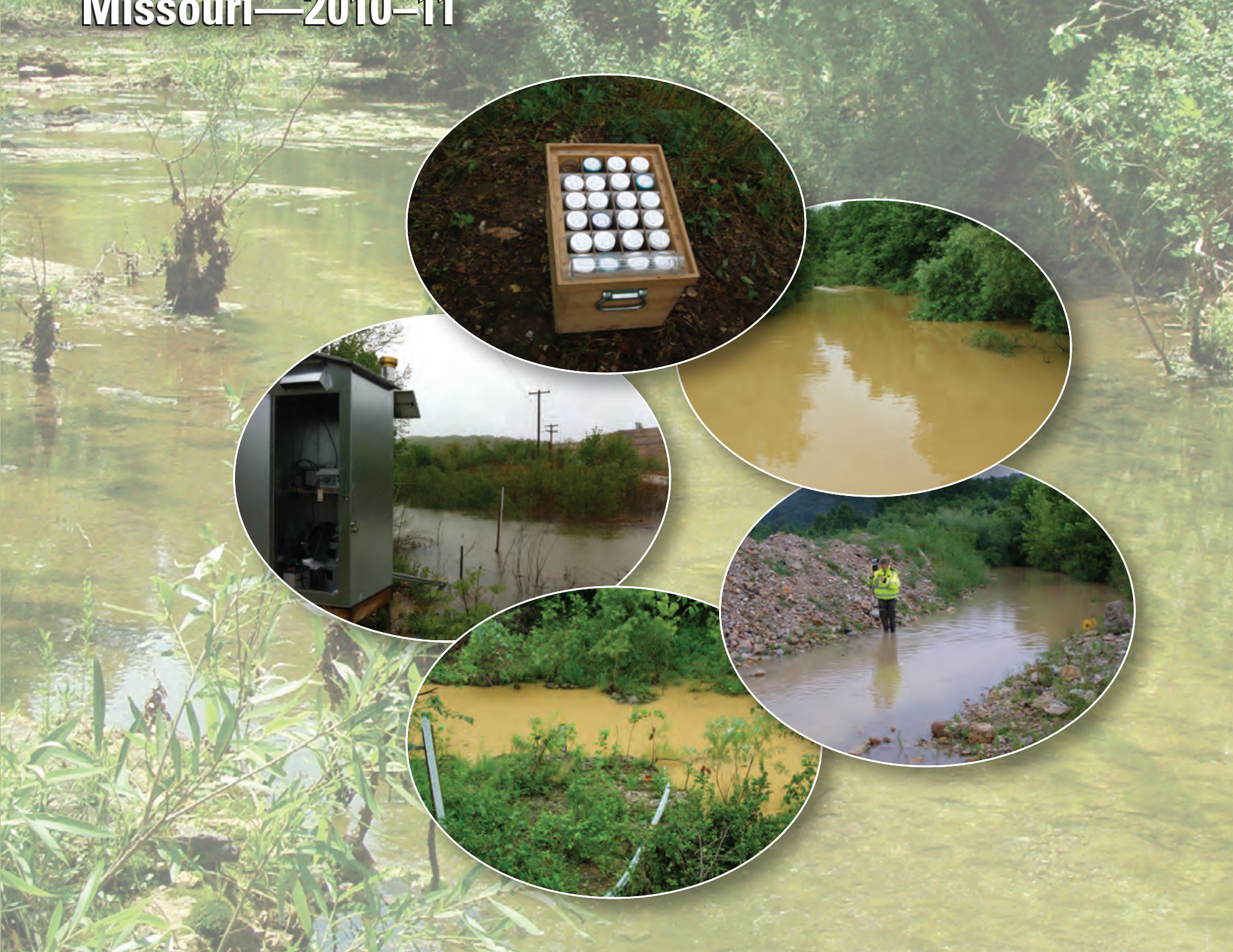

Scientificthvestigations heport 2012-5268

U.S. Departument of the lnteliter U.S. Eeclogical SuIvey 
Cover: Photographs from various locations at the Fort Leonard Wood Military Reservation. 


\section{Hydrologic and Sediment Data Collected From Selected Basins at the Fort Leonard Wood Military Reservation, Missouri-2010-11}

By Joseph M. Richards, Paul H. Rydlund, and Miya N. Barr

Prepared in cooperation with U.S. Army Maneuver Support Center at the Fort Leonard Wood Military Reservation

Scientific Investigations Report 2012-5268 


\section{U.S. Department of the Interior \\ KEN SALAZAR, Secretary \\ U.S. Geological Survey \\ Marcia K. McNutt, Director}

\section{U.S. Geological Survey, Reston, Virginia: 2012}

For more information on the USGS - the Federal source for science about the Earth, its natural and living resources, natural hazards, and the environment, visit http://www.usgs.gov or call 1-888-ASK-USGS.

For an overview of USGS information products, including maps, imagery, and publications, visit http://www.usgs.gov/pubprod

To order this and other USGS information products, visit http://store.usgs.gov

Any use of trade, firm, or product names is for descriptive purposes only and does not imply endorsement by the U.S. Government.

Although this information product, for the most part, is in the public domain, it also may contain copyrighted materials as noted in the text. Permission to reproduce copyrighted items must be secured from the copyright owner.

Suggested citation:

Richards, J.M., Rydlund, P.H., and Barr, M.N., 2012, Hydrologic and sediment data collected from selected basins at the Fort Leonard Wood Military Reservation, Missouri-2010-11: U.S. Geological Survey Scientific Investigations Report 2012-5268, 23 p. 


\section{Contents}

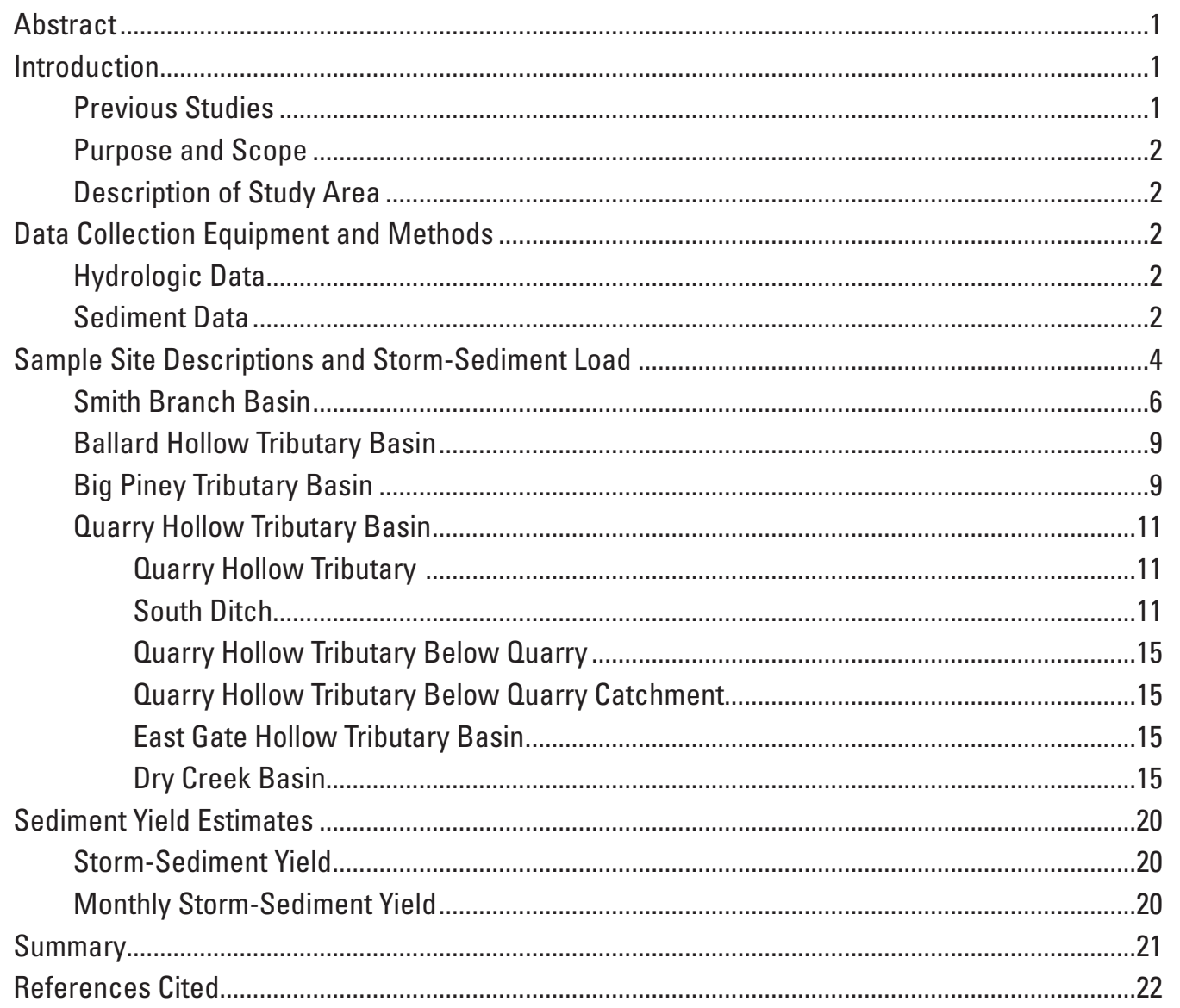




\section{Figures}

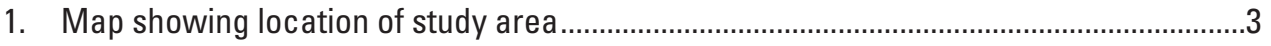

2. Map showing location of data collection sites..............................................................

3. Graph showing example storm-event hydrograph and sediment sample collection plot at East Gate Hollow tributary (06930058) for the July 30, 2011, storm event. ............6

4. Graph showing Smith Branch (06928400) discharge hydrograph, hyetograph, and sediment sample collection dates ..........................................................................10

5. Graph showing Ballard Hollow tributary (06928410) discharge hydrograph, hyetograph, and sediment sample collection dates...

6. Graph showing Big Piney tributary (06930025) discharge hydrograph and sediment sample collection dates

7. Graph showing Quarry Hollow tributary (06930023) discharge hydrograph, hyetograph, and sediment sample collection dates.

8. Graph showing Quarry Hollow tributary below quarry (06930027) discharge hydrograph, hyetograph, and sediment sample collection dates.

9. Graph showing Quarry Hollow tributary below quarry catchment (06930028) discharge hydrograph and sediment sample collection dates.

10. Graph showing East Gate Hollow tributary (06930058) discharge hydrograph, hyetograph, and sediment sample collection dates

11. Graph showing Dry Creek (06930250) discharge hydrograph and sediment sample collection dates...

\section{Tables}

1. Hydrologic and sediment data collection sites at the Fort Leonard Wood Military Reservation, Missouri

2. Sampled runoff volume, event-mean suspended-sediment concentration, sediment load, and sediment yield for selected basins at the Fort Leonard Wood Military Reservation, Missouri.

3. Total monthly precipitation (inches) in selected basins at the Fort Leonard Wood Military Reservation, Missouri

4. Estimated monthly storm-sediment yield (tons per square mile) in selected basins at the Fort Leonard Wood Military Reservation, Missouri. 


\section{Conversion Factors}

Inch/Pound to SI

\begin{tabular}{|c|c|c|}
\hline Multiply & By & To obtain \\
\hline \multicolumn{3}{|c|}{ Length } \\
\hline inch (in.) & 2.54 & centimeter $(\mathrm{cm})$ \\
\hline inch (in.) & 25.4 & millimeter (mm) \\
\hline foot $(\mathrm{ft})$ & 0.3048 & meter $(\mathrm{m})$ \\
\hline mile (mi) & 1.609 & kilometer $(\mathrm{km})$ \\
\hline \multicolumn{3}{|c|}{ Area } \\
\hline acre & 4,047 & square meter $\left(\mathrm{m}^{2}\right)$ \\
\hline square mile $\left(\mathrm{mi}^{2}\right)$ & 2.590 & square kilometer $\left(\mathrm{km}^{2}\right)$ \\
\hline \multicolumn{3}{|c|}{ Volume } \\
\hline cubic foot $\left(\mathrm{ft}^{3}\right)$ & 0.02832 & cubic meter $\left(\mathrm{m}^{3}\right)$ \\
\hline cubic yard $\left(\mathrm{yd}^{3}\right)$ & 0.7646 & cubic meter $\left(\mathrm{m}^{3}\right)$ \\
\hline \multicolumn{3}{|c|}{ Flow rate } \\
\hline cubic foot per second $\left(\mathrm{ft}^{3} / \mathrm{s}\right)$ & 0.02832 & cubic meter per second $\left(\mathrm{m}^{3} / \mathrm{s}\right)$ \\
\hline inch per year (in/yr) & 25.4 & millimeter per year (mm/yr) \\
\hline \multicolumn{3}{|c|}{ Mass } \\
\hline pound, avoirdupois (lb) & 0.4536 & kilogram (kg) \\
\hline ton, short $(2,000 \mathrm{lb})$ & 0.9072 & megagram $(\mathrm{Mg})$ \\
\hline ton per day (ton/d) & 0.9072 & metric ton per day \\
\hline ton per day (ton/d) & 0.9072 & megagram per day $(\mathrm{Mg} / \mathrm{d})$ \\
\hline \multicolumn{3}{|l|}{ ton per square mile } \\
\hline$\left(\operatorname{ton} / \mathrm{mi}^{2}\right)$ & 0.3503 & megagram per square \\
\hline \multicolumn{3}{|l|}{ kilometer $\left(\mathrm{Mg} / \mathrm{km}^{2}\right)$} \\
\hline ton per year (ton/yr) & 0.9072 & megagram per year $(\mathrm{Mg} / \mathrm{yr})$ \\
\hline ton per year (ton/yr) & 0.9072 & metric ton per year \\
\hline \multicolumn{3}{|c|}{ Density } \\
\hline pound per cubic foot $\left(\mathrm{lb} / \mathrm{ft}^{3}\right)$ & 16.02 & kilogram per cubic meter $\left(\mathrm{kg} / \mathrm{m}^{3}\right)$ \\
\hline pound per cubic foot $\left(\mathrm{lb} / \mathrm{ft}^{3}\right)$ & 0.01602 & gram per cubic centimeter $\left(\mathrm{g} / \mathrm{cm}^{3}\right)$ \\
\hline ton per cubic foot $\left(\operatorname{ton} / \mathrm{ft}^{3}\right)$ & 0.02569 & metric ton per cubic meter \\
\hline
\end{tabular}

Horizontal coordinate information is referenced to the North American Datum of 1983 (NAD 83).

Concentrations of chemical constituents in water are given either in milligrams per liter $(\mathrm{mg} / \mathrm{L})$ or micrograms per liter $(\mu \mathrm{g} / \mathrm{L})$. 



\title{
Hydrologic and Sediment Data Collected From Selected Basins at the Fort Leonard Wood Military Reservation, Missouri-2010-11
}

\author{
By Joseph M. Richards, Paul H. Rydlund, and Miya N. Barr
}

\begin{abstract}
Commercial and residential development within a basin often increases the amount of impervious area, which changes the natural hydrologic response to storm events by increasing runoff. Land development and disturbance combined with increased runoff from impervious areas potentially can increase sediment transport. At the Fort Leonard Wood Military Reservation in Missouri, there has been an increase in population and construction activities in the recent past, which has initiated an assessment of the hydrology in selected basins. From April 2010 to December 2011, the U.S. Geological Survey, in cooperation with the U.S. Army Maneuver Support Center at the Fort Leonard Wood Military Reservation, collected hydrologic and suspended-sediment concentration data in six basins at Fort Leonard Wood.

Storm-sediment concentration, load, and yield varied from basin to basin and from storm to storm. In general, storm-sediment yield, in pounds per square mile per minute, was greatest from Ballard Hollow tributary (06928410) and Dry Creek (06930250), and monthly storm-sediment yield, in tons per square mile, estimates were largest in Ballard Hollow tributary (06928410), East Gate Hollow tributary (06930058), and Dry Creek (06930250).

Sediment samples, collected at nine sites, primarily were collected using automatic samplers and augmented with equal-width-increment cross-sectional samples and manually collected samples when necessary. Storm-sediment load and yield were computed from discharge and suspended-sediment concentration data. Monthly storm-sediment yields also were estimated from the total storm discharge and the mean suspended-sediment concentration at each given site.
\end{abstract}

\section{Introduction}

Commercial and residential development within a basin often increases the amount of impervious area, which changes the natural hydrologic response to storm events by increasing runoff. Increases in runoff lead to stream deformation, down-cutting, and bank erosion, which results in excess sediment, a leading cause of water quality impairment throughout the United States. From 2000 to 2010, population has increased more than 10 percent at the Fort Leonard Wood Military Reservation (FLWMR) in Missouri (U.S. Census Bureau, 2011). This population growth and an increase in construction activities within the cantonment area of the FLWMR prompted an investigation of hydrologic changes and potential stream impairment. The U.S. Geological Survey (USGS), in cooperation with the U.S. Army Maneuver Support Center (MANSCEN) at FLWMR, began a study in April 2010 to collect hydrologic and suspended-sediment concentration (SSC) data in selected basins within the FLWMR. The FLWMR is under the regulation of the Missouri Clean Water Law and Federal Clean Water Act and the data collected by this study will help satisfy some requirements for a Municipal Separate Storm Sewer System (MS4) permit required by the Missouri Department of Natural Resources (Shannon Kelly, Fort Leonard Wood, oral commun., 2012).

\section{Previous Studies}

Several previous studies relating to issues of surfacewater and groundwater quantity and quality have been completed at the FLWMR, many of which are described in Imes and others (1996). Imes and others (1996) reported the results of a study designed to characterize the regional surface-water and groundwater quantity and quality in the vicinity of the FLWMR relating to environmental contamination that may have resulted from historic operational practices. Harrison and others (1996) mapped the geology, characterized bedrock structures potentially affecting groundwater flow, and mapped many karst features at the FLWMR and adjacent areas.

Kleeschulte and Imes (1997) described the regional groundwater flow system and how the karst terrane that underlies the FLWMR affects the local and regional flow system. 


\section{Purpose and Scope}

The report describes the methods used to collect localscale, surface-water hydrologic and sediment data during storm events in selected basins at the FLWMR. The report also presents the data that were collected from April 2010 to December 2011 and the associated storm-sediment yield.

\section{Description of Study Area}

FLWMR is located in the southern part of Pulaski County, Missouri (fig. 1) and lies within the Salem Plateau of the Ozark Plateaus Physiographic Province (Fenneman, 1938). The FLWMR is approximately 64,000 acres in size and is bounded to the east by the Big Piney River, to the west by Roubidoux Creek, to the north by Interstate 44 , and to the south by publicly and privately owned hardwood forest land (fig. 1; Kleeschulte and Imes, 1997). The mean annual precipitation in the area is approximately 42 inches (Imes and others, 1996). The rocks exposed in the area are Ordovician age and are dominantly carbonate composition. Soils in most of the area consist of silty and sandy loam to very cherty silty loam derived from locally weathered bedrock (Harrison and others, 1996). Some loess deposits of wind-blown silty loam, colluvial material on the steep hillsides, and recent alluvial fill along larger streams also are present in lesser amounts (Harrison and others, 1996). Karst features such as springs, sinkholes, caves, and losing streams are common at the FLWMR and can affect groundwater and surface-water flow (Imes and others, 1996; Kleeschulte and Imes, 1997).

\section{Data Collection Equipment and Methods}

For this study, streamgages were installed and streamflow and SSC data were collected at six basins designated by MANSCEN within the FLWMR boundary (table 1; fig. 2). Each basin had one co-located streamgage and sediment sampling site except for the Quarry Hollow Tributary Basin. The Quarry Hollow Tributary Basin had three co-located streamgage and sediment sampling sites designed to evaluate the sediment contribution from the open gravel quarry located near the basin outlet. An additional sediment sampling site (South ditch, USGS station number 374313092042401) within the Quarry Hollow Tributary Basin was not co-located with a streamgage. This site was sampled manually for sediment six times during four storms to determine the sediment contribution to the Quarry Hollow Tributary Basin from this site (table 1; fig. 2).

Various equipment and methods were used to collect hydrologic and SSC data for this study. Because the basins monitored in this study were small, many of the basins had no flow for much of the study. The study was designed to collect hydrologic data primarily during storm events; therefore, in some basins that did have a small base flow component, streamgage equipment was not always set up to record this base flow. Because of the emphasis on storm events, few lowflow discharge measurements were made for this study. Storm events generally produced hydrographs that rose rapidly to the peak discharge and receded almost as quickly to pre-storm discharge values. The storm-event hydrographs generally were short in duration and sediment samples only were collected during storm events (fig. 3).

\section{Hydrologic Data}

The equipment used to collect stage data at each site consisted of a pressure transducer that measured the stage in the stream and a data logger that stored the stage data at 5-minute intervals (Buchanan and Somers, 1974). Continuous stage data collected by the data logger at each site were stored in the USGS National Water Information System (NWIS) database (Sauer, 2002) and were used to determine the peak stage and the hydrograph of stage versus time for any given storm event. Discharge measurements were made using hydroacoustic equipment according to the methods outlined in Mueller and Wagner (2009) and Turnipseed and Sauer (2010). USGS personnel used the discharge measurements to establish the stage-discharge relation for each site (Kennedy, 1984; Kennedy, 1989).

Precipitation data were collected by an existing National Weather Service rain gage, number 03938 (not shown on a figure), located at the FLWMR Forney Army Airport (fig. 1; National Oceanic and Atmospheric Administration, n.d.), and augmented with precipitation data collected using tipping bucket rain gages installed at select sites (table 1). Data from these rain gages were stored in the streamgage data logger.

The stage and precipitation data were transmitted by satellite to a USGS computer and served on the internet in near real time. After collection, all hydrologic data were quality assured and stored in the NWIS database.

\section{Sediment Data}

Sediment samples were collected primarily with an automatic sampler (Sigma 900MAX) that was housed inside the streamgage and connected to the data logger. Sediment samples were collected from one fixed point in the water column, and the sampler orifice location generally was positioned on the bank near the streamgage. The streamgage data logger was programmed to collect stage, compute discharge, and compute the volume of water that passed the monitoring site during 5 -minute increments. The stage data and volume computations were used to initiate sampling by the automatic sampler, which collected a flow-weighted sediment sample during each sampled storm event. A SSC was analyzed from sample water that was pumped into sample collection bottles by a 12-volt peristaltic pump housed in the automatic sampler. As a result 


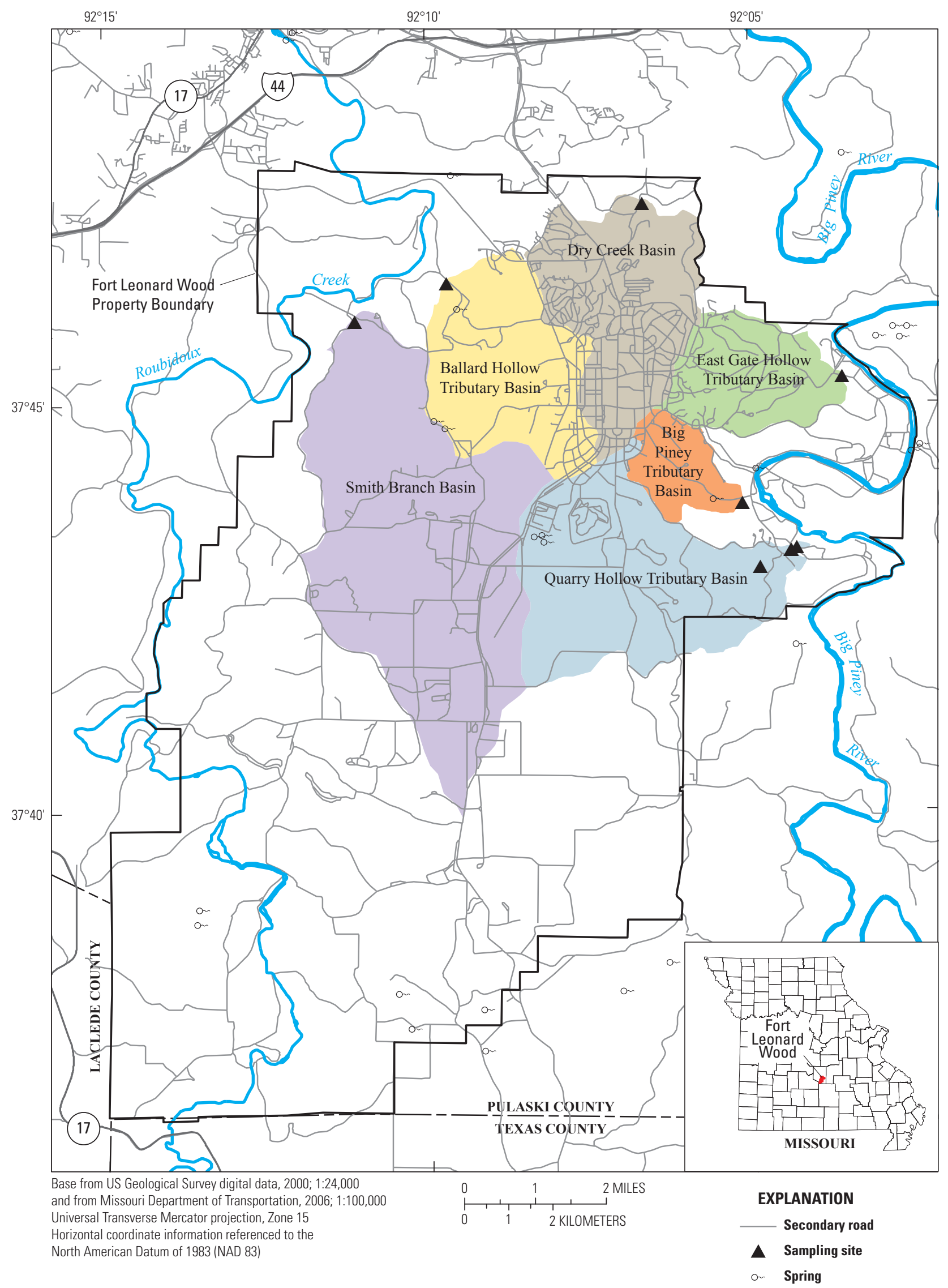

Figure 1. Location of study area. 
Table 1. Hydrologic and sediment data collection sites at the Fort Leonard Wood Military Reservation, Missouri.

$\left[\mathrm{mi}^{2}\right.$, square miles; $\mathrm{Y}$, yes; $\mathrm{N}, \mathrm{No} ;--$, no period of record $]$

\begin{tabular}{|c|c|c|c|c|c|c|c|}
\hline \multirow[b]{2}{*}{ Site number } & \multirow[b]{2}{*}{ Site name } & \multirow{2}{*}{$\begin{array}{c}\text { Drainage } \\
\text { area } \\
\left(\mathbf{m i}^{2}\right)\end{array}$} & \multirow{2}{*}{$\begin{array}{c}\text { Drainage } \\
\text { area } \\
\text { (acres) }\end{array}$} & \multicolumn{2}{|c|}{ Period of record } & \multirow[b]{2}{*}{$\begin{array}{l}\text { Precipitation } \\
\text { data }\end{array}$} & \multirow[b]{2}{*}{$\begin{array}{l}\text { Events } \\
\text { sampled }\end{array}$} \\
\hline & & & & From & To & & \\
\hline 06928400 & Smith Branch & 13.8 & 8,812 & $6 / 10 / 2010$ & $12 / 28 / 2011$ & $\mathrm{Y}$ & 4 \\
\hline 06928410 & Ballard Hollow tributary & 5.31 & 3,401 & $4 / 16 / 2010$ & $12 / 28 / 2011$ & Y & 13 \\
\hline 06930025 & Big Piney tributary & 1.54 & 984 & $6 / 2 / 2010$ & $12 / 3 / 2010$ & $\mathrm{~N}$ & 14 \\
\hline 06930023 & Quarry Hollow tributary & 7.44 & 4,765 & $4 / 16 / 2010$ & $12 / 28 / 2011$ & Y & 11 \\
\hline 374313092042401 & South ditch & 0.05 & 29 & -- & -- & $\mathrm{N}$ & 4 \\
\hline 06930027 & $\begin{array}{l}\text { Quarry Hollow tributary } \\
\text { below quarry }\end{array}$ & 8.01 & 5,128 & $1 / 26 / 2011$ & $12 / 23 / 2011$ & Y & 7 \\
\hline 06930028 & $\begin{array}{l}\text { Quarry Hollow tributary } \\
\text { below quarry catchment }\end{array}$ & 8.03 & 5,139 & $5 / 13 / 2010$ & $12 / 27 / 2011$ & $\mathrm{~N}$ & 3 \\
\hline 06930058 & East Gate Hollow tributary & 3.18 & 2,033 & $4 / 23 / 2010$ & $12 / 27 / 2011$ & Y & 15 \\
\hline 06930250 & Dry Creek & 5.63 & 3,605 & 4/16/2010 & $12 / 28 / 2011$ & $\mathrm{~N}$ & 15 \\
\hline
\end{tabular}

of short hydrograph duration times and event-driven protocol, sediment point samples from the automatic samplers were not calibrated to equal-width-increment (EWI) cross-sectional sediment samples.

The sites were visited after each storm to verify peak stage values and to retrieve sample collection bottles from the automatic samplers. Early in the project, while the stagedischarge relation was being developed, a mean SSC was computed from individual samples that were collected at specific points on the discharge hydrograph. Later in the project, samples collected throughout the discharge hydrograph were composited into a single bottle and SSC was determined from the composited sample. In addition, sediment samples occasionally were collected by hand, and when stream conditions were suitable for wading, sediment samples were collected manually using a DH-81 sampler and the EWI method (Edwards and Glysson, 1999; Lane and others, 2003). These samples were collected to augment the automatically collected samples, to provide quality assurance/quality control data for the automatically collected samples, to provide opportunistic samples at additional sites, or to provide a sample when the automatic sampler failed to operate correctly.

Sediment samples were transported to and analyzed by the USGS Missouri Water Science Center sediment laboratory. Laboratory analysis for SSC was performed in accordance to the filtration methods described in Guy (1969).

\section{Sample Site Descriptions and Storm- Sediment Load}

Every precipitation event has the potential of eroding and moving sediment from the land surface. Factors affecting the amount and type of sediment eroded from the landscape and washed into receiving streams include soil type, land use, land cover, land slope, precipitation intensity, precipitation volume, antecedent moisture conditions, and physical stream channel characteristics. Thus, differences in SSC and sediment load in a given stream can have many causes. Sediment load is the mass of sediment material moved by stream water past a fixed point in space and consists of two components: bed sediment load and suspended-sediment load. Bed sediment moves by rolling, sliding, or bouncing along the bed of the stream, and suspended sediment moves by being carried along in suspension in the water column (Sturm, 2001). Sediment sampled in this study was the suspended-sediment part of the sediment load.

For this study, the event-mean SSC and the sampled runoff volume were used to compute a sediment load associated with the sampled storm at each sampling site (table 2). The event-mean SSC was computed from the arithmetic mean of the individual SSC samples collected throughout the hydrograph or was the laboratory-determined composite SSC. The sampled runoff volume was the sum of the incremental discharge (5-minute intervals) of water that passed the streamgage between the time the first and last samples were collected (fig. 3). For most of the storm events, the stage rose rapidly and thus most of the sediment sample collection was on the peak and falling limb of the hydrograph (fig. 3). The load represents the sediment mass passing the streamgage 


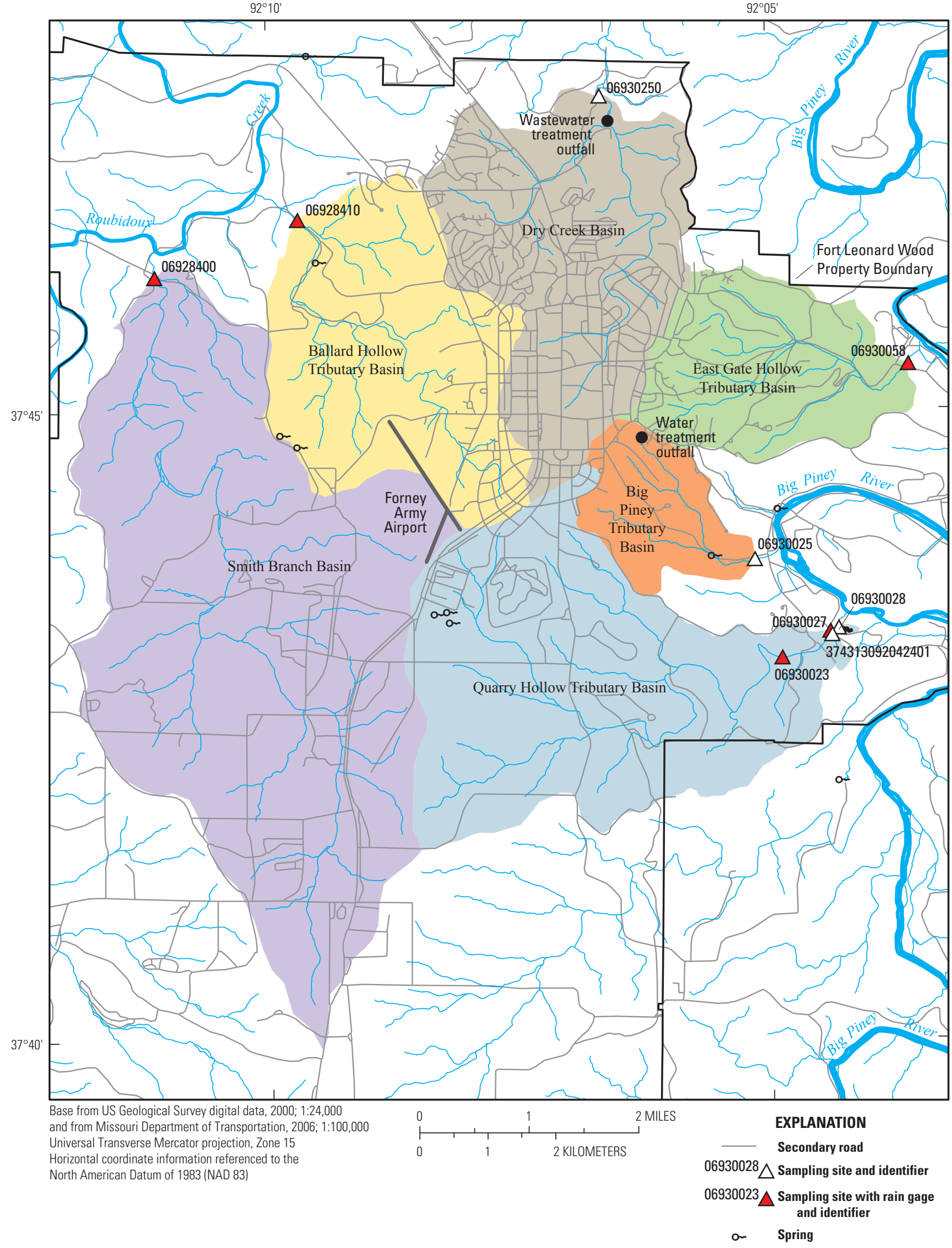

Figure 2. Location of data collection sites. 


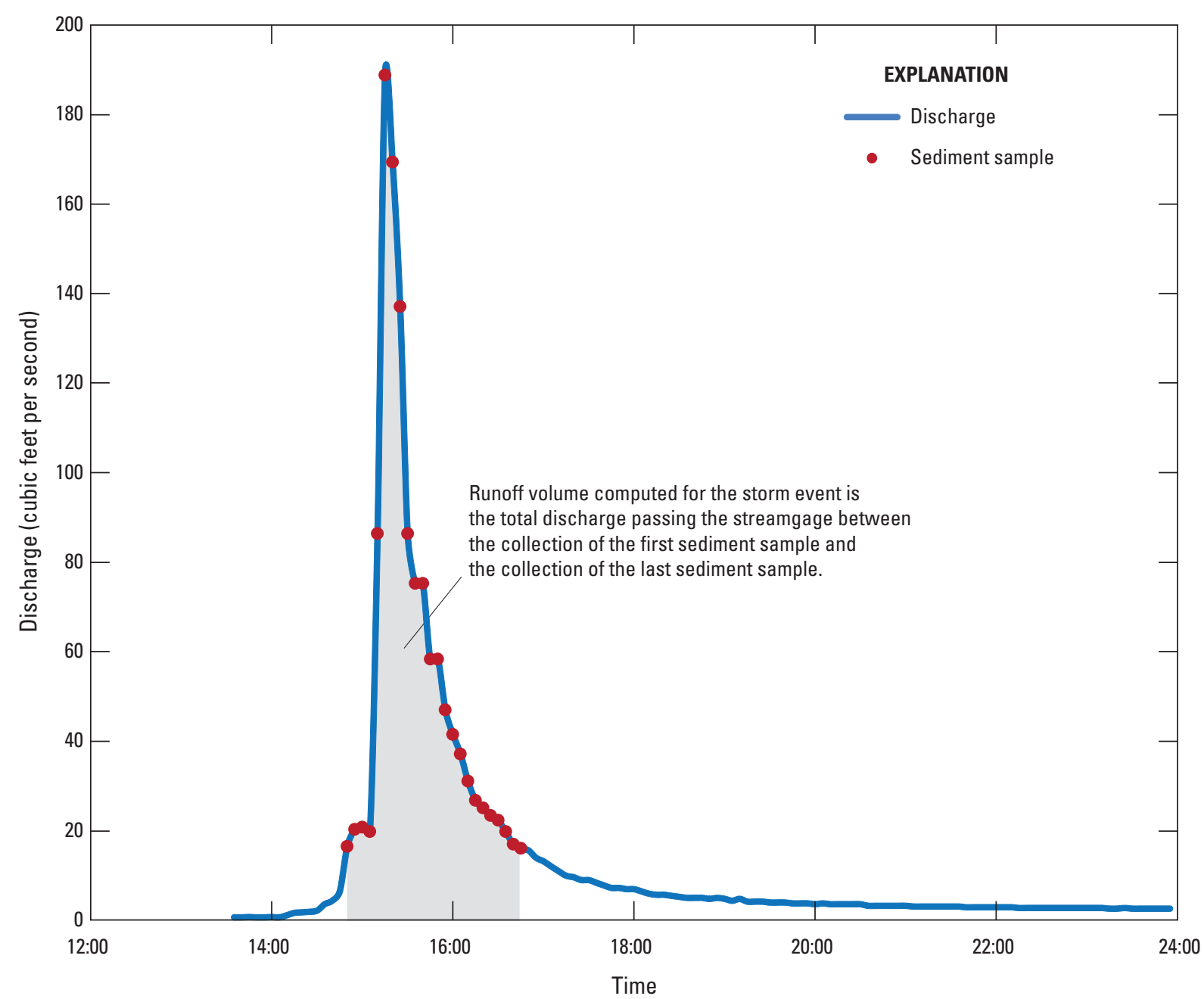

Figure 3. Example storm-event hydrograph and sediment sample collection plot at East Gate Hollow tributary (06930058) for the July 30, 2011, storm event.

during the sampling period and may not accurately represent the mass of sediment passing the streamgage for the entire storm event. In some cases, the sediment sampling period coincided very well with the storm runoff period; however, in other cases, few samples were collected throughout the hydrograph and thus the sediment sampling period does not coincide with the storm runoff period.

Sediment load for a given sampling event $(i)$ was computed using the following equation:

$$
L O A D_{i}=E M C_{i} \times R V_{i} \times\left(6.245 \times 10^{-5}\right)
$$

where

$L O A D_{i} \quad$ is sediment load (in pounds) for event $i$,

$E M C_{i} \quad$ is event-mean suspended-sediment concentration (in milligrams per liter) for event $i$,

$R V_{i} \quad$ is runoff volume (in cubic feet) for event $i$, and

$6.245 \times 10^{-5}$ is the conversion from milligrams per liter to pounds per cubic foot.

\section{Smith Branch Basin}

The Smith Branch sampling site (06928400; fig. 2) was located approximately 0.29 miles upstream from the confluence of Smith Branch with Roubidoux Creek. The drainage area at the streamgage was 13.8 square miles $\left(\mathrm{mi}^{2}\right.$; table 1$)$, and the channel at the streamgage was narrow and steep sided with a bedrock bottom. Imes and others (1996) did not measure this stream during a low-base flow seepage run on Roubidoux Creek. During the period of this study, Smith Branch did not flow except during, and shortly after, storm events (fig. 4).

Storm events were successfully sampled at this site four times (table 1; fig. 4). The SSC for all storms sampled ranged from 222 to 1,210 milligrams per liter $(\mathrm{mg} / \mathrm{L})$ and had a mean of $481 \mathrm{mg} / \mathrm{L}$ (table 2). The sediment load ranged from 76.8 to 383,000 pounds (table 2). A precipitation hyetograph for this site is shown in figure 4 , and monthly precipitation totals are presented in table 3 . 
Table 2. Sampled runoff volume, event-mean suspended-sediment concentration, sediment load, and sediment yield for selected basins at the Fort Leonard Wood Military Reservation, Missouri.

$\left[\mathrm{ft}^{3}\right.$, cubic foot; $\mathrm{mg} / \mathrm{L}$, milligrams per liter; $\mathrm{lb}$, pound; $\left(\mathrm{lb} / \mathrm{mi}^{2}\right) / \mathrm{min}$, pounds per square mile per minute; --, no data

\begin{tabular}{|c|c|c|c|c|}
\hline Storm event date & $\begin{array}{l}\text { Sampled runoff volume } \\
\qquad\left(\mathrm{ft}^{3}\right)\end{array}$ & $\begin{array}{l}\text { Event-mean suspended- } \\
\text { sediment concentration } \\
\text { (mg/L) }\end{array}$ & $\begin{array}{l}\text { Sediment load } \\
\text { (lb) }\end{array}$ & $\begin{array}{c}\text { Sediment yield } \\
{\left[\left(\mathrm{lb} / \mathrm{mi}^{2}\right) / \mathrm{min}\right]}\end{array}$ \\
\hline \multicolumn{5}{|c|}{ Smith Branch (06928400) } \\
\hline $07 / 09 / 2010$ & 5,490 & 224 & 76.8 & 1.12 \\
\hline $07 / 26 / 2010$ & $5,070,000$ & 1,210 & 383,000 & 232 \\
\hline $11 / 25 / 2010$ & $1,990,000$ & 269 & 33,400 & 14.3 \\
\hline $02 / 24 / 2011$ & 767,000 & 222 & 10,600 & 19.2 \\
\hline \multicolumn{5}{|c|}{ Ballard Hollow tributary (06928410) } \\
\hline $07 / 08 / 2010$ & 858,000 & 1,480 & 79,300 & 119 \\
\hline $09 / 01 / 2010$ & 175,000 & 1,550 & 16,900 & 127 \\
\hline $11 / 25 / 2010$ & 214,000 & 855 & 11,400 & 61.3 \\
\hline $04 / 15 / 2011$ & $1,510,000$ & 1,050 & 99,000 & 117 \\
\hline $04 / 23 / 2011$ & $1,280,000$ & 642 & 51,300 & 55.2 \\
\hline $04 / 25 / 2011$ & 624,000 & 482 & 18,800 & 20.8 \\
\hline $05 / 12 / 2011$ & $1,030,000$ & 465 & 29,900 & 32.2 \\
\hline 05/19/2011 & 811,000 & 512 & 25,900 & 39.0 \\
\hline 05/20/2011 & 760,000 & 253 & 12,000 & 15.1 \\
\hline $05 / 28 / 2011$ & 265,000 & 617 & 10,200 & 34.9 \\
\hline $08 / 04 / 2011$ & 901,000 & 863 & 48,600 & 67.8 \\
\hline 08/20/2011 & 335,000 & 363 & 7,590 & 20.4 \\
\hline 09/18/2011 & 346,000 & 452 & 9,770 & 28.3 \\
\hline \multicolumn{5}{|c|}{ Big Piney tributary (06930025) } \\
\hline${ }^{1} 06 / 20 / 2010$ & 14,700 & 313 & 287 & -- \\
\hline${ }^{1} 06 / 26 / 2010$ & 22,700 & 365 & 517 & -- \\
\hline${ }^{1} 06 / 27 / 2010$ & 21,400 & 286 & 382 & -- \\
\hline${ }^{1} 07 / 03 / 2010$ & 20,800 & 263 & 342 & -- \\
\hline${ }^{1} 07 / 05 / 2010$ & 17,900 & 190 & 212 & -- \\
\hline${ }^{1} 07 / 07 / 2010$ & 35,900 & 198 & 444 & -- \\
\hline${ }^{1} 08 / 08 / 2010$ & 20,200 & 281 & 354 & -- \\
\hline${ }^{1} 08 / 13 / 2010$ & 11,200 & 228 & 159 & -- \\
\hline${ }^{1} 08 / 14 / 2010$ & 12,500 & 250 & 195 & -- \\
\hline${ }^{1} 08 / 16 / 2010$ & 31,500 & 183 & 360 & -- \\
\hline${ }^{1} 08 / 18 / 2010$ & 32,700 & 180 & 368 & -- \\
\hline${ }^{1} 08 / 20 / 2010$ & 3,450 & 736 & 159 & -- \\
\hline${ }^{1} 08 / 21 / 2010$ & 22,500 & 268 & 377 & -- \\
\hline${ }^{1} 08 / 22 / 2010$ & 20,700 & 138 & 178 & -- \\
\hline \multicolumn{5}{|c|}{ Quarry Hollow tributary (06930023) } \\
\hline $02 / 24 / 2011$ & 249,000 & 512 & 7,960 & 7.38 \\
\hline $02 / 27 / 2011$ & 186,000 & 2,630 & 30,500 & 41.0 \\
\hline 03/14/2011 & 833,000 & 545 & 28,400 & 11.4 \\
\hline $04 / 15 / 2011$ & 229,000 & 906 & 13,000 & 15.9 \\
\hline $04 / 22 / 2011$ & 165,000 & 332 & 3,420 & 3.41 \\
\hline
\end{tabular}


Table 2. Sampled runoff volume, event-mean suspended-sediment concentration, sediment load, and sediment yield for selected basins at the Fort Leonard Wood Military Reservation, Missouri.-Continued

$\left[\mathrm{ft}^{3}\right.$, cubic foot; $\mathrm{mg} / \mathrm{L}$, milligrams per liter; $\mathrm{lb}$, pound; $\left(\mathrm{lb} / \mathrm{mi}^{2}\right) / \mathrm{min}$, pounds per square mile per minute; --, no data

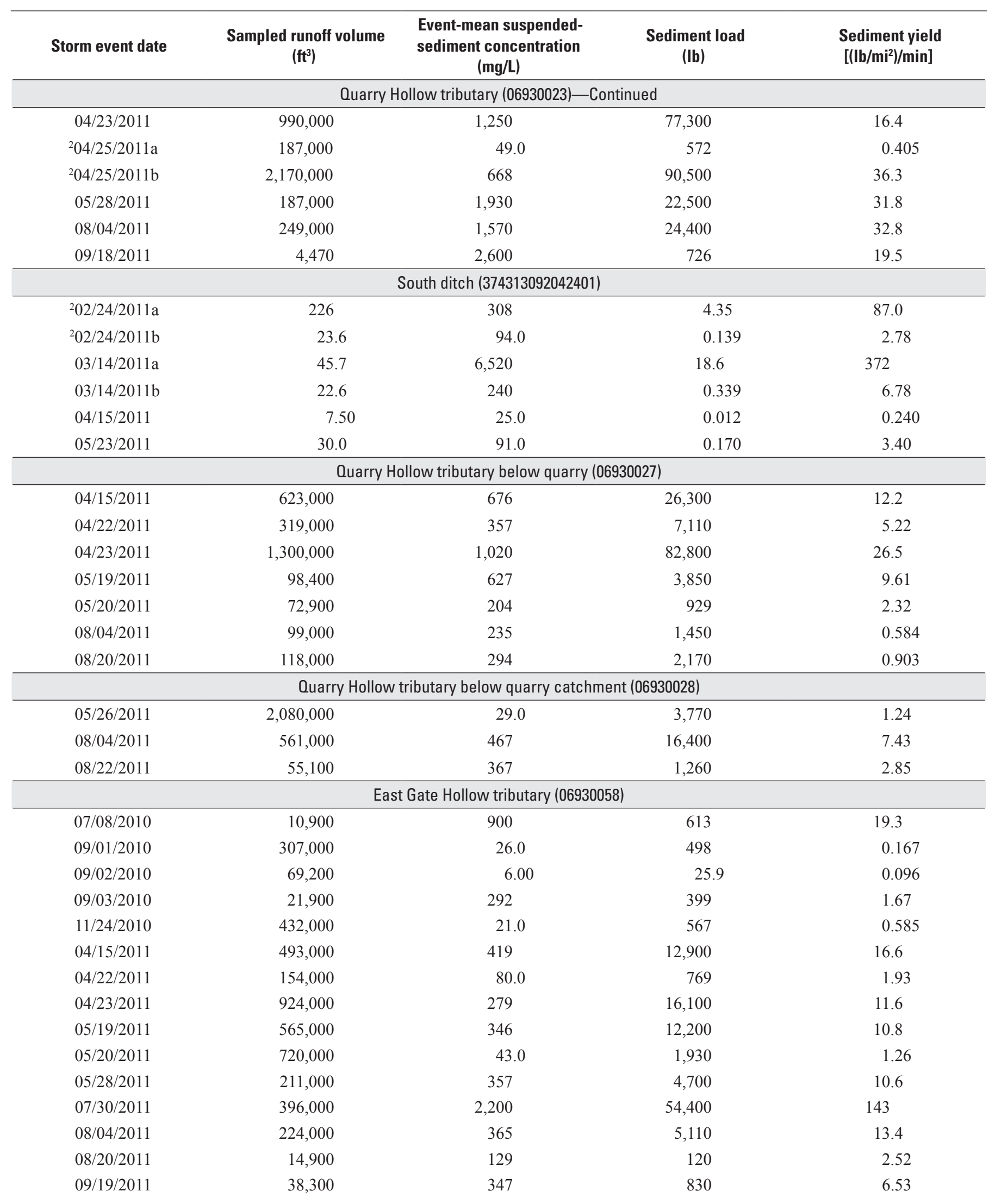


Table 2. Sampled runoff volume, event-mean suspended-sediment concentration, sediment load, and sediment yield for selected basins at the Fort Leonard Wood Military Reservation, Missouri.-Continued

$\left[\mathrm{ft}^{3}\right.$, cubic foot; $\mathrm{mg} / \mathrm{L}$, milligrams per liter; $\mathrm{lb}$, pound; $\left(\mathrm{lb} / \mathrm{mi}^{2}\right) / \mathrm{min}$, pounds per square mile per minute; --, no data

\begin{tabular}{|c|c|c|c|c|}
\hline Storm event date & $\begin{array}{l}\text { Sampled runoff volume } \\
\qquad\left(\mathrm{ft}^{3}\right)\end{array}$ & $\begin{array}{l}\text { Event-mean suspended- } \\
\text { sediment concentration } \\
\text { (mg/L) }\end{array}$ & $\begin{array}{l}\text { Sediment load } \\
\text { (Ib) }\end{array}$ & $\begin{array}{l}\text { Sediment yield } \\
{\left[\left(\mathrm{lb} / \mathrm{mi}^{2}\right) / \mathrm{min}\right]}\end{array}$ \\
\hline $06 / 15 / 2010$ & 48,300 & 449 & 1,350 & 16.0 \\
\hline $07 / 08 / 2010$ & $2,090,000$ & 681 & 88,900 & 126 \\
\hline $07 / 26 / 2010$ & 895,000 & 394 & 22,000 & 20.6 \\
\hline $08 / 21 / 2010$ & 256,000 & 572 & 9,140 & 7.06 \\
\hline 09/01/2010 & $1,490,000$ & 868 & 80,800 & 169 \\
\hline $11 / 24 / 2010$ & $2,340,000$ & 353 & 51,600 & 55.5 \\
\hline $04 / 15 / 2011$ & $3,160,000$ & 1,070 & 211,000 & 341 \\
\hline $04 / 23 / 2011$ & $2,060,000$ & 667 & 85,800 & 92.4 \\
\hline $04 / 25 / 2011$ & $4,370,000$ & 510 & 139,000 & 165 \\
\hline $05 / 12 / 2011$ & $1,050,000$ & 385 & 25,200 & 63.9 \\
\hline 05/19/2011 & $1,970,000$ & 543 & 66,800 & 148 \\
\hline 05/20/2011 & 323,000 & 213 & 4,300 & 38.2 \\
\hline 07/30/2011 & 888,000 & 1,290 & 71,500 & 317 \\
\hline 08/04/2011 & $2,150,000$ & 780 & 105,000 & 219 \\
\hline 09/17/2011 & 82,300 & 637 & 3,270 & 10.6 \\
\hline
\end{tabular}

${ }^{1}$ Samples affected by release of water from water-treatment sediment-settling ponds upstream from the gage and data not representative of storm events in the basin.

${ }^{2}$ Two samples collected in the same day.

\section{Ballard Hollow Tributary Basin}

The Ballard Hollow tributary sampling site (06928410; fig. 2) was located approximately 0.47 miles upstream from the confluence of Ballard Hollow tributary with Roubidoux Creek. The drainage area at the streamgage was $5.31 \mathrm{mi}^{2}$ (table 1). The channel at the streamgage was narrow and steep sided with a gravel and cobble bottom. Imes and others (1996) measured 0.18 cubic foot per second $\left(\mathrm{ft}^{3} / \mathrm{s}\right)$ at this stream during a low-base flow seepage run on Roubidoux Creek. The streamgage orifice elevation at this site was set such that flow less than approximately $12.2 \mathrm{ft}^{3} / \mathrm{s}$ was not recorded by the streamgage.

Storm events were successfully sampled at this site thirteen times (table 1; fig. 5). The SSC for all storms sampled ranged from 253 to $1,550 \mathrm{mg} / \mathrm{L}$ and had a mean of $737 \mathrm{mg} / \mathrm{L}$ (table 2). The sediment load ranged from 7,590 to 99,000 pounds (table 2). A precipitation hyetograph for this site is shown in figure 5 , and monthly precipitation totals are presented in table 3.

\section{Big Piney Tributary Basin}

The Big Piney tributary sampling site (06930025) was located approximately 0.33 miles upstream from the confluence of the Big Piney tributary with the Big Piney River. The drainage area at the streamgage was $1.54 \mathrm{mi}^{2}$ (table 1). A small amount of base flow is maintained by a spring that discharges to the tributary approximately $0.42 \mathrm{mi}$ upstream from the streamgage. Imes and others (1996) did not measure this stream during a low-base flow seepage run on the Big Piney River. The streamgage orifice elevation at this site was set such that flow less than approximately $0.55 \mathrm{ft}^{3} / \mathrm{s}$ was not recorded by the streamgage.

The outfall for the water-treatment sediment-settling ponds for the drinking water intake from the Big Piney River is located near the basin divide (Shannon Kelly, Fort Leonard Wood, oral commun., 2012; fig. 2). The settling ponds are periodically (once a day or once every other day) drained to the headwaters of the Big Piney tributary. The presence of the settling ponds and periodic water release was not known to the USGS at the time of the installation and operation of the streamgage and subsequent sediment sampling; therefore, the gage was relocated to the Quarry Hollow Tributary Basin in early 2011. It is unclear if any of the sediment samples that were collected from this basin were associated with a storm event. It is believed most, if not all, of the sediment samples collected in this basin were collected from the water that was released from the settling pond. 


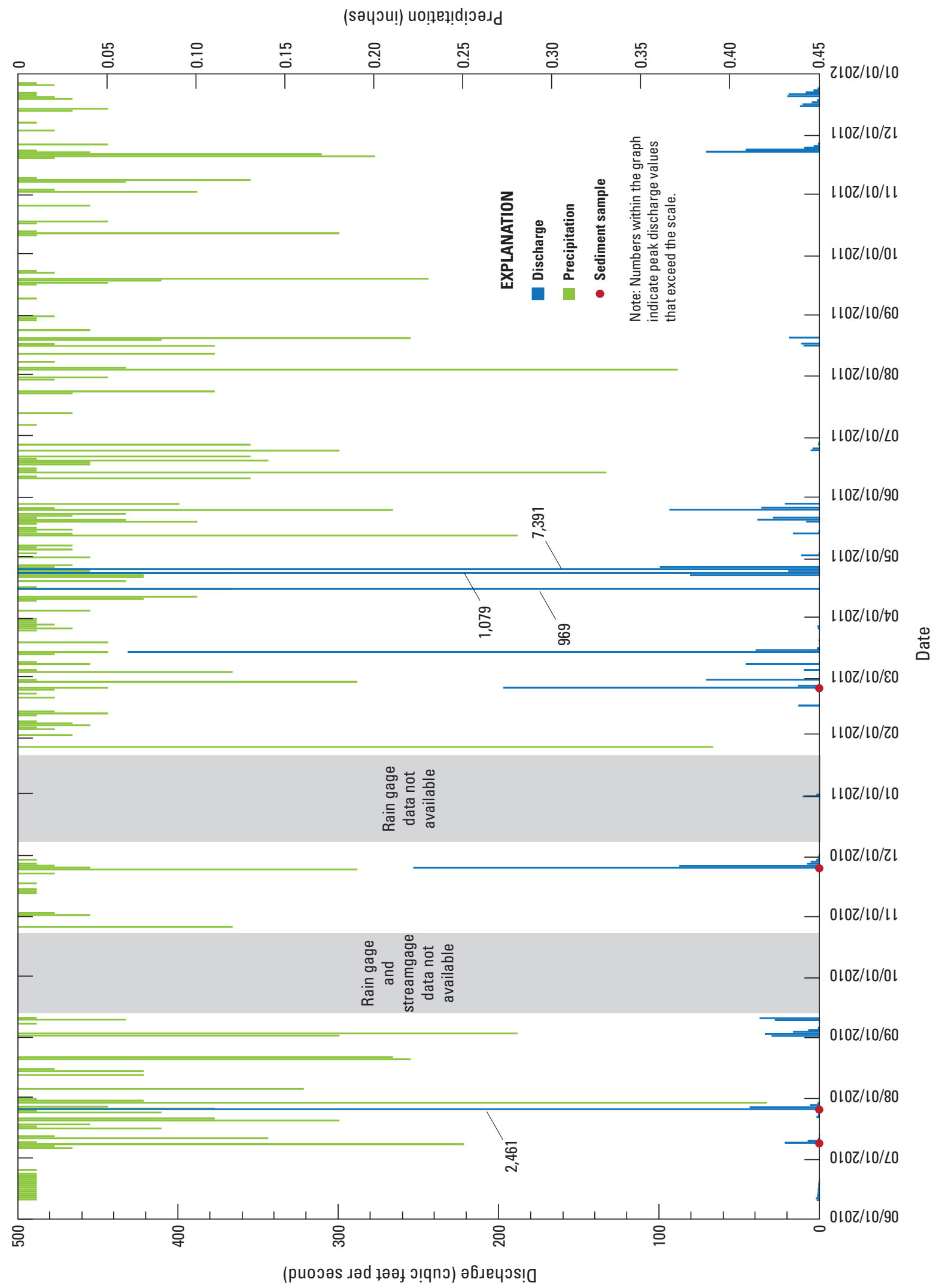


Table 3. Total monthly precipitation (inches) in selected basins at the Fort Leonard Wood Military Reservation, Missouri.

[--, no data $]$

\begin{tabular}{|c|c|c|c|c|c|c|}
\hline \multirow[b]{2}{*}{$\begin{array}{c}\text { Date } \\
\text { (month year) }\end{array}$} & \multicolumn{6}{|c|}{ Precipitation (inches) } \\
\hline & $\begin{array}{c}\text { Forney Army } \\
\text { Airport }\end{array}$ & $\begin{array}{c}\text { Smith Branch } \\
(06928400)\end{array}$ & $\begin{array}{c}\text { Ballard Hollow } \\
\text { tributary } \\
(06928410)\end{array}$ & $\begin{array}{c}\text { Quarry Hollow } \\
\text { tributary } \\
(06930023)\end{array}$ & $\begin{array}{l}\text { Quarry Hollow } \\
\text { tributary } \\
\text { below quarry } \\
\text { (06930027) }\end{array}$ & $\begin{array}{c}\text { East Gate } \\
\text { Hollow tributary } \\
\text { (06930058) }\end{array}$ \\
\hline April 2010 & 2.08 & -- & 12.19 & ${ }^{1} 1.70$ & -- & ${ }^{1} 1.49$ \\
\hline May 2010 & 6.00 & -- & 6.44 & 6.59 & -- & 6.52 \\
\hline June 2010 & 4.61 & ${ }^{1} 0.24$ & 4.81 & 3.92 & -- & 4.97 \\
\hline July 2010 & 4.83 & 7.00 & 7.57 & 5.87 & -- & 6.25 \\
\hline August 2010 & 2.00 & 2.70 & 2.91 & 2.22 & -- & 1.95 \\
\hline September 2010 & 7.72 & ${ }^{1} 5.98$ & 8.66 & ${ }^{1} 5.34$ & -- & 7.77 \\
\hline October 2010 & 0.36 & ${ }^{1} 0.17$ & ${ }^{1} 0.01$ & -- & -- & 0.34 \\
\hline November 2010 & 4.02 & 4.45 & 3.67 & -- & -- & 3.84 \\
\hline December 2010 & 0.64 & ${ }^{1} 0$ & 1.86 & 1.05 & -- & 1.12 \\
\hline January 2011 & 0.27 & ${ }^{1} 0.59$ & 0.28 & 0.43 & ${ }^{1} 0$ & 0.39 \\
\hline February 2011 & 3.16 & 6.53 & 3.89 & 3.91 & 2.55 & 3.63 \\
\hline March 2011 & 5.27 & 5.61 & 5.73 & 5.22 & 5.19 & 5.27 \\
\hline April 2011 & 6.98 & 8.25 & 7.90 & 8.79 & 7.90 & 8.43 \\
\hline May 2011 & 7.05 & 7.77 & 7.34 & 7.11 & 5.79 & 7.54 \\
\hline June 2011 & 4.14 & 4.33 & 3.93 & 5.43 & 5.05 & 3.76 \\
\hline July 2011 & 1.16 & 0.86 & 0.68 & 3.22 & 3.50 & 3.43 \\
\hline August 2011 & 6.05 & 5.95 & 5.55 & 6.02 & 6.81 & 5.02 \\
\hline September 2011 & 2.79 & 2.23 & 2.41 & 3.14 & 3.21 & 2.51 \\
\hline October 2011 & 2.21 & 2.23 & 1.86 & 2.57 & 2.43 & 2.34 \\
\hline November 2011 & 3.85 & 5.81 & 5.23 & 4.46 & 4.24 & 3.65 \\
\hline December 2011 & 2.57 & 2.84 & 2.68 & 2.79 & 2.20 & 2.83 \\
\hline
\end{tabular}

${ }^{1}$ Values based on partial month record.

SSCs from this site were not considered to be representative of storm-sediment transport in this basin and therefore rainfall data were not included on figure 6 . Nevertheless, fourteen samples were successfully collected at this site (table 1; fig. 6). The SSC for all samples ranged from 138 to $736 \mathrm{mg} / \mathrm{L}$ and had a mean of $277 \mathrm{mg} / \mathrm{L}$ (table 2). The sediment load ranged from 159 to 517 pounds (table 2).

\section{Quarry Hollow Tributary Basin}

The Quarry Hollow Tributary Basin was more intensively studied because of an active gravel quarry operation for an onsite asphalt plant. Imes and others (1996) estimated base flow of $0.07 \mathrm{ft}^{3} / \mathrm{s}$ in this basin during a low-base flow seepage run on the Big Piney River. The streamgage orifice elevation at the furthest upstream site, Quarry Hollow tributary (06930023; fig. 2), was set such that flow less than approximately $5.27 \mathrm{ft}^{3} / \mathrm{s}$ was not recorded by the streamgage (fig. 7).

\section{Quarry Hollow Tributary}

The Quarry Hollow tributary sampling site (06930023; fig. 2) was located approximately 0.97 miles upstream from the confluence of the Quarry Hollow tributary with the Big Piney River. The channel at the streamgage was narrow and had a gravel and cobble bottom, and was located adjacent to the asphalt plant and upstream from the quarry. The drainage area at the streamgage was $7.44 \mathrm{mi}^{2}$ (table 1).

Storm events were successfully sampled at this site eleven times (table 1; fig. 7). The SSC for all storms sampled ranged from 49.0 to $2,630 \mathrm{mg} / \mathrm{L}$ and had a mean of $1,181 \mathrm{mg} / \mathrm{L}$ (table 2). The sediment load ranged from 572 to 90,500 pounds (table 2). A precipitation hyetograph for this site is shown in figure 7, and monthly precipitation totals are presented in table 3 . 


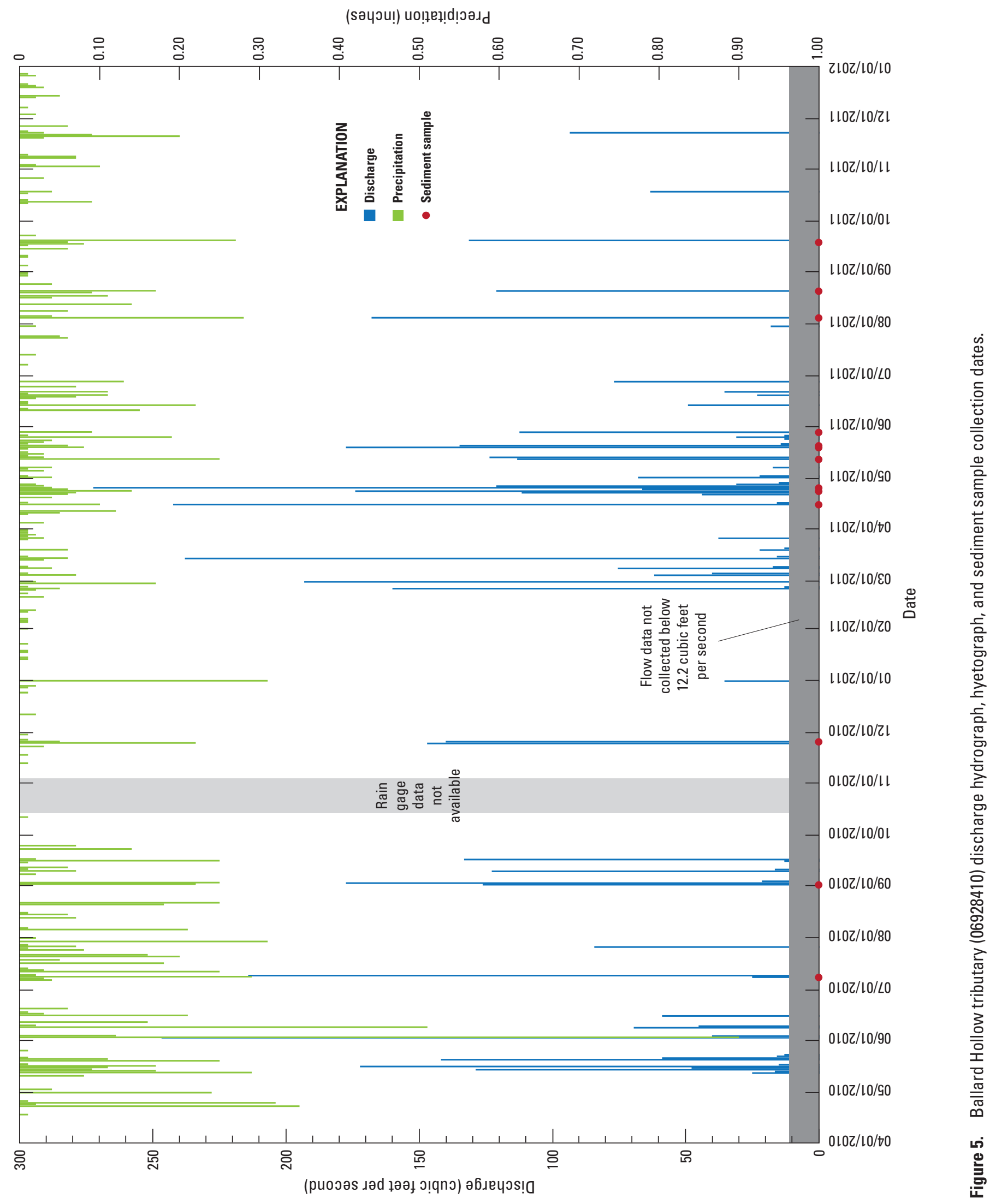




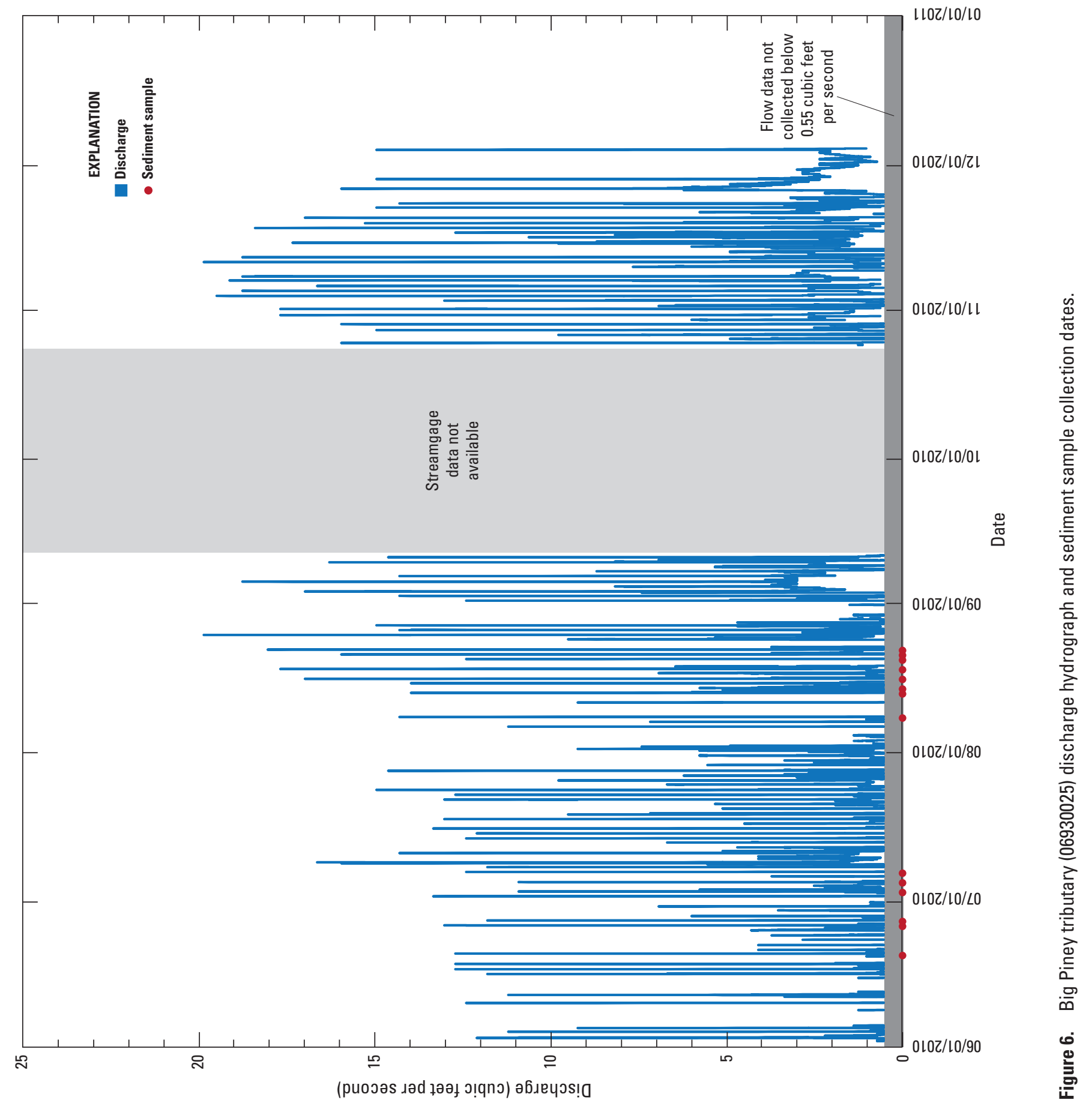




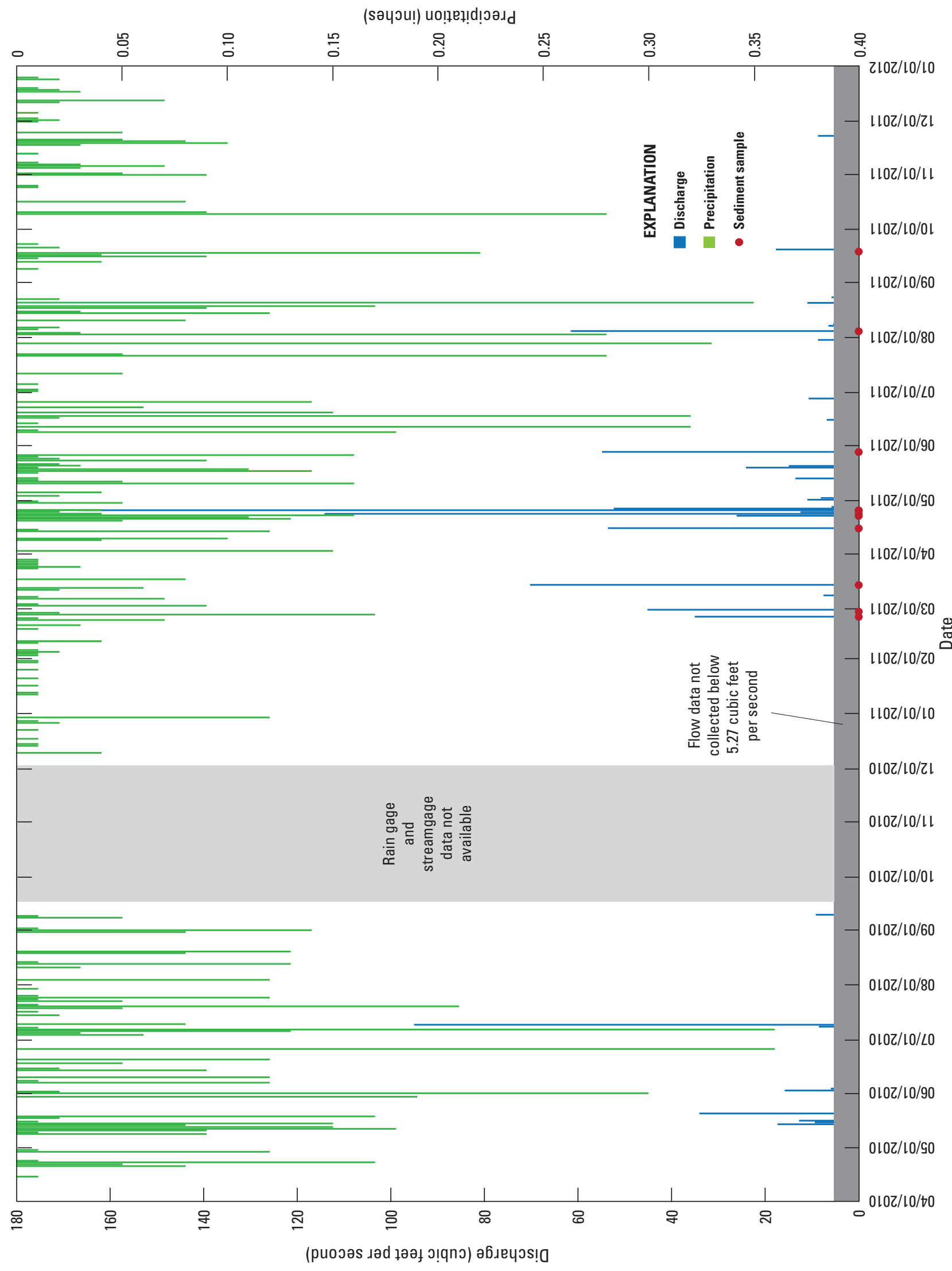




\section{South Ditch}

The South ditch sampling site (374313092042401; fig. 2) was located approximately 50 feet upstream from the confluence of the South ditch with the Quarry Hollow tributary. The South ditch flows into the Quarry Hollow tributary approximately 50 feet upstream from the Quarry Hollow tributary below quarry (06930027; fig. 2) sampling site. This ditch flows northward and drains the southern part of the quarry. The drainage area of the ditch at the sampling point was 29 acres.

Manual EWI samples were collected at this site during four storm events to attempt to determine the sediment input from this ditch to the Quarry Hollow tributary. The SSC for all samples ranged from 25.0 to $6,520 \mathrm{mg} / \mathrm{L}$, and sediment loads ranged from 0.012 pounds on April 15, 2011 to 18.6 pounds on March 14, 2011 (table 2). Measured flow at this site had a mean of $0.99 \mathrm{ft}^{3} / \mathrm{s}$ for the six samples collected.

\section{Quarry Hollow Tributary Below Quarry}

The Quarry Hollow tributary below quarry sampling site (06930027; fig. 2) was located approximately 0.41 miles upstream from the confluence of the Quarry Hollow tributary with the Big Piney River, and is approximately 50 feet downstream from the quarry. The drainage area at the streamgage was $8.01 \mathrm{mi}^{2}$ (table 1). The channel at the gage was narrow and partly filled with fine gravel that seemed to be partly derived from the quarry. Sediment transport and redistribution during storm events at this site frequently buried or occluded the orifice of the automatic sampler and made it difficult to obtain a representative sample.

Storm events were successfully sampled at this site seven times (table 1; fig. 8). The SSC for all storms sampled ranged from 204 to $1,020 \mathrm{mg} / \mathrm{L}$ and had a mean of $488 \mathrm{mg} / \mathrm{L}$ (table 2). The sediment load ranged from 929 to 82,800 pounds (table 2). A precipitation hyetograph for this site is shown in figure 8 , and monthly precipitation totals are presented in table 3 .

\section{Quarry Hollow Tributary Below Quarry Catchment}

The Quarry Hollow tributary below quarry catchment sampling site (06930028; fig. 2) was located approximately 0.21 miles upstream from the confluence of the Quarry Hollow tributary with the Big Piney River and had a drainage area of $8.03 \mathrm{mi}^{2}$ (table 1). This site was located approximately 260 feet downstream from a 2.3 -acre sediment settlement basin designed to help mitigate the flow of sediment to the Big Piney River. Substantial amounts of organic detritus were observed in the water in the settlement basin and in flow exiting the settlement basin during storm events. This organic material frequently buried or occluded the orifice of the automatic sampler and made it difficult to get a representative sample at this site. This site also was susceptible to backwater effects from the Big Piney River. Because the point of zero flow was difficult to determine in the field at this site, a low flow extrapolation of the discharge rating was terminated at a streamgage height of $0.13 \mathrm{ft}\left(0.45 \mathrm{ft}^{3} / \mathrm{s}\right)$. The resulting discharge record along with sampled runoff volume and stormsediment load computations were not substantially affected by this rating definition for storm event analysis.

Storm events were successfully sampled at this site three times (table 1; fig. 9). The SSC for all storms sampled ranged from 29 to $467 \mathrm{mg} / \mathrm{L}$ and had a mean of $288 \mathrm{mg} / \mathrm{L}$ (table 2). The sediment load ranged from 1,260 to 16,400 pounds (table 2).

\section{East Gate Hollow Tributary Basin}

The East Gate Hollow tributary sampling site (06930058; fig. 2) was located approximately $0.17 \mathrm{mi}$ upstream from the confluence of the East Gate Hollow tributary with the Big Piney River. The East Gate Hollow tributary maintained a small base flow throughout the study, presumably from spring discharge in the basin. The drainage area at the streamgage was $3.18 \mathrm{mi}^{2}$ (table 1). The channel at the streamgage was narrow, steep sided, and had a gravel bottom. Imes and others (1996) did not measure this stream during their low-base flow seepage run on the Big Piney River. This site had continuous flow throughout the period of study with a minimum recorded discharge of $0.11 \mathrm{ft}^{3} / \mathrm{s}$.

Storm events were successfully sampled at this site fifteen times (table 1; fig. 10). The SSC for all storms sampled ranged from 6 to $2,200 \mathrm{mg} / \mathrm{L}$ and had a mean of $387 \mathrm{mg} / \mathrm{L}$ (table 2). The sediment load ranged from 25.9 to 54,400 pounds (table 2). A precipitation hyetograph for this site is shown in figure 10, and monthly precipitation totals are presented in table 3 .

\section{Dry Creek Basin}

The Dry Creek sampling site (06930250; fig. 2) was located approximately $4.1 \mathrm{mi}$ upstream from confluence of Dry Creek with the Big Piney River and approximately $0.3 \mathrm{mi}$ downstream from the Fort Leonard Wood wastewater treatment plant. The drainage area was $5.63 \mathrm{mi}^{2}$ (table 1), and the channel at the streamgage was narrow and had a gravel and cobble bottom with exposed bedrock in many places. Dry Creek receives discharge from the wastewater treatment plant; however, the discharge is lost to the groundwater before the flow gets to the streamgage. Imes and others (1996) observed zero flow at its confluence with the Big Piney River during their low-base flow seepage run. During the period of this study, it is assumed that Dry Creek did not flow except during and shortly after storm events (fig. 11). Rainfall data from nearby rain gages was inconclusive for matching runoff with associated rainfall, probably because of the variable nature of runoff-producing rainfall in the study basin. 


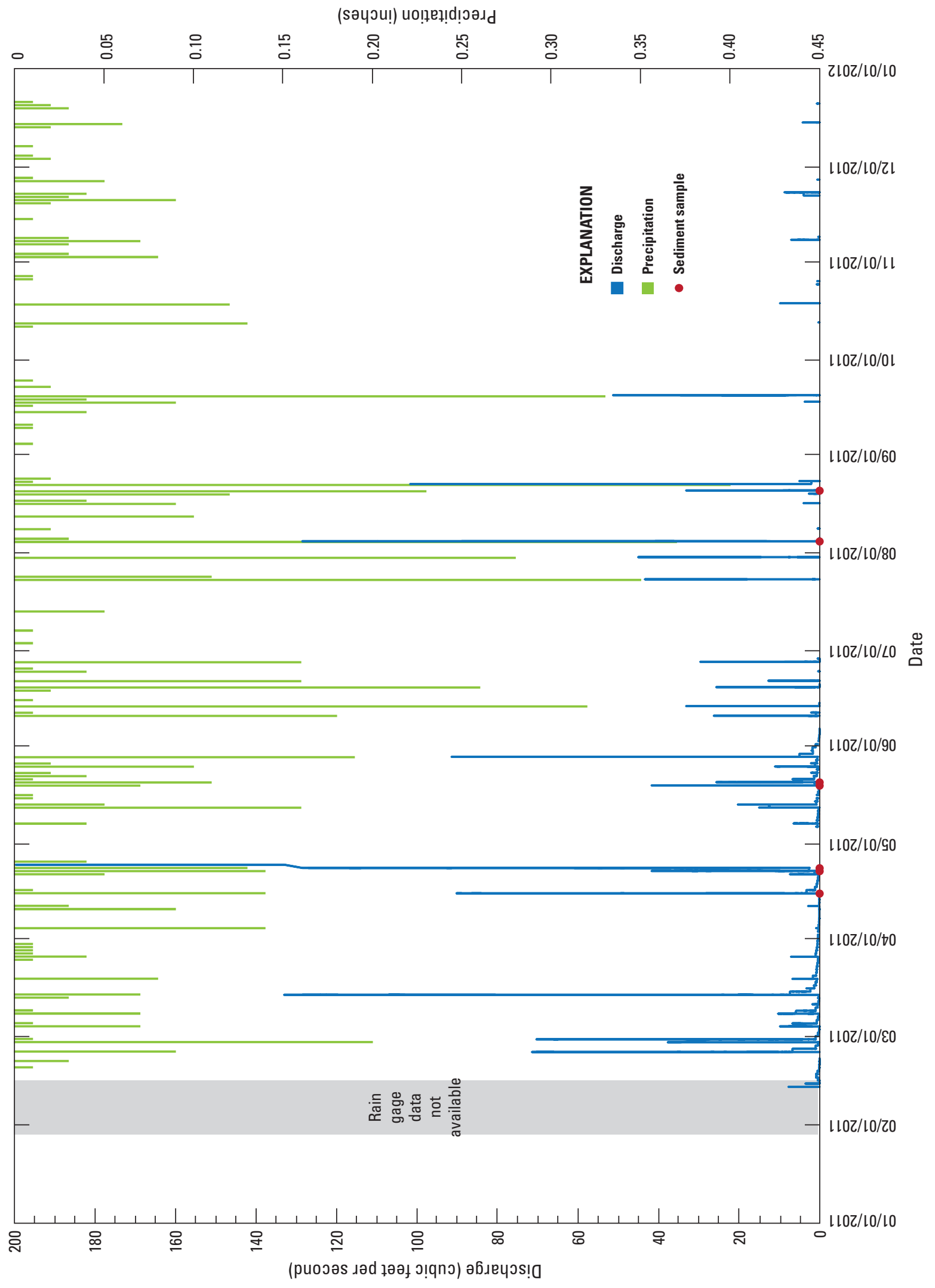




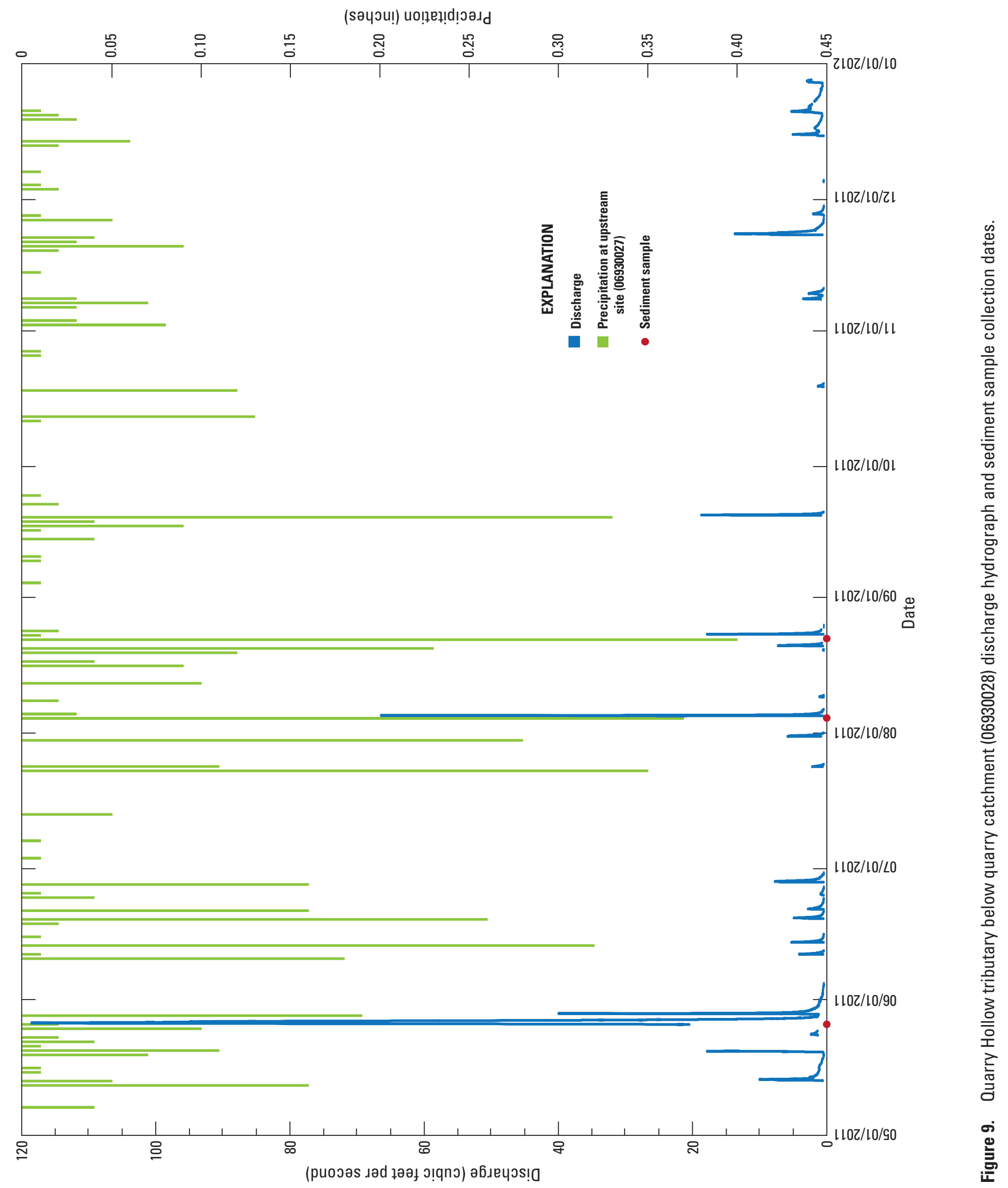




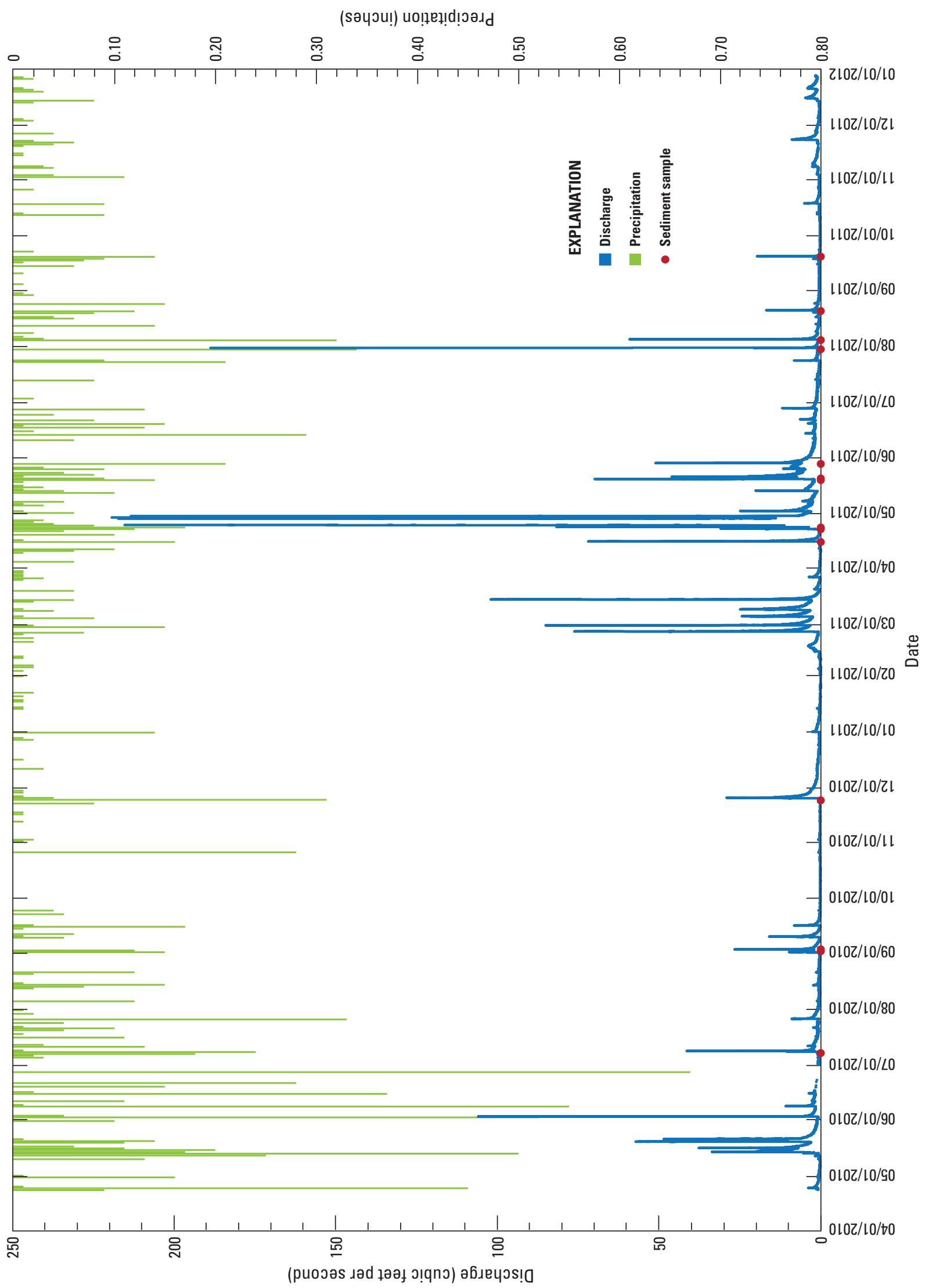




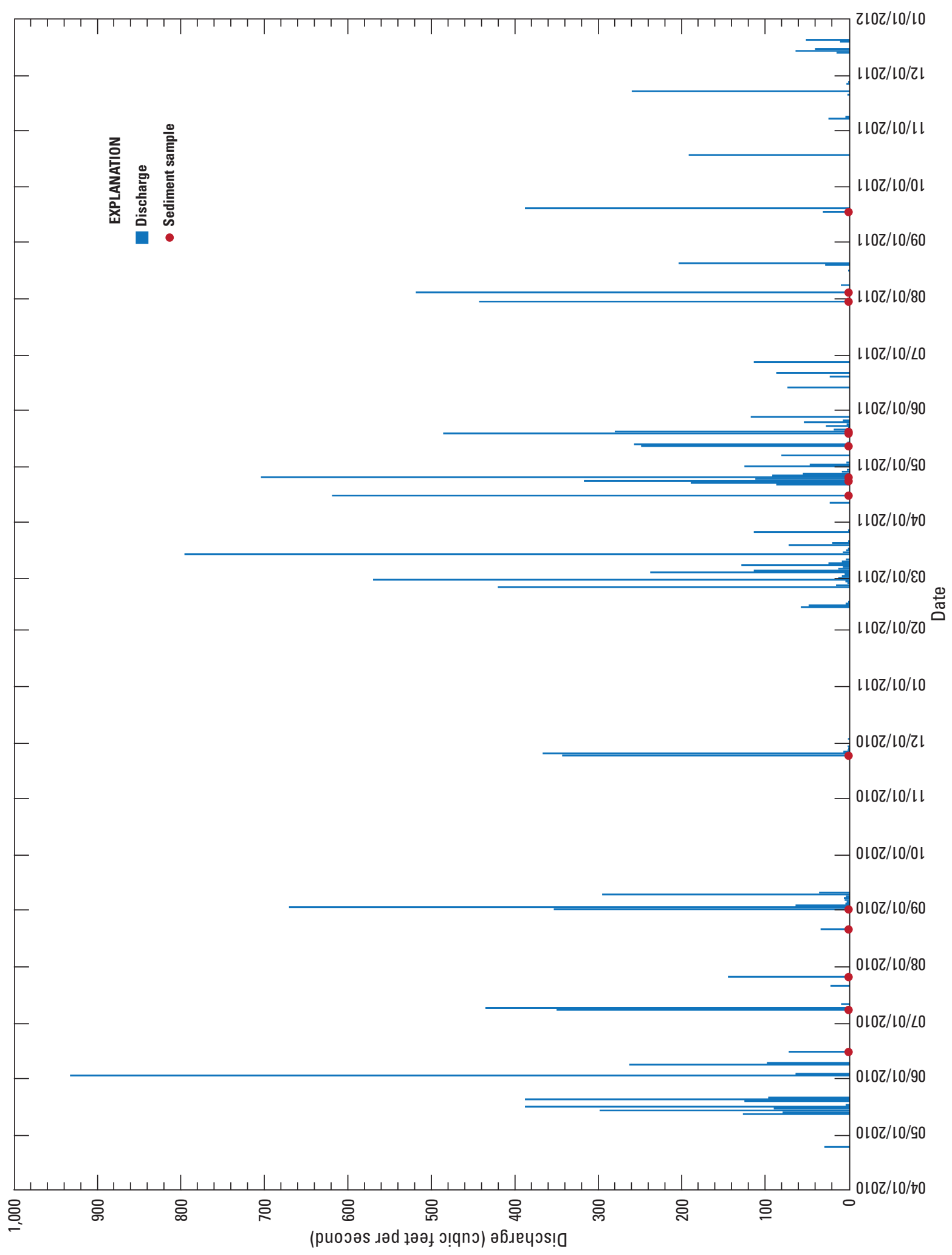


Storm events were successfully sampled at this site fifteen times (table 1; fig. 11). The SSC for all storms sampled ranged from 213 to $1,290 \mathrm{mg} / \mathrm{L}$ and had a mean of $627 \mathrm{mg} / \mathrm{L}$ (table 2). The sediment load ranged from 1,350 to 211,000 pounds (table 2).

\section{Sediment Yield Estimates}

Sediment yield is the amount of material removed from the land surface by erosion in a given unit of time per unit area of the basin. Sediment yield is computed to normalize the sediment load by basin area and by time so that differences in basin size and sampling duration can be ignored when comparing the values between basins (table 2). Sediment yield is computed using the following equation:

$$
Y_{I E L D_{i}}=\frac{\operatorname{LOAD}_{i}}{D A \times S A M P L E D_{\text {DUATION }}}
$$

where

$$
\begin{aligned}
& Y I E L D_{i} \quad \text { is sediment yield (in (pounds per square mile) } \\
& \text { per minute) for event } i \text {, } \\
& L O A D_{i} \quad \text { is constituent load (in pounds) for event } i \text {, } \\
& D A \quad \text { is the drainage area of the selected basin (in } \\
& \text { square miles), and } \\
& \begin{array}{l}
\text { SAMPLE } \\
\text { DURATION }
\end{array} \\
& \text { DURATION }_{i} \text { for event } i \text {. }
\end{aligned}
$$

Yield was computed for each site for each sampled storm (storm-sediment yield) and estimated for each site for all storms by month (monthly storm-sediment yield). Because sediment samples were not collected for all storm events at any given site, monthly storm-sediment yield was computed to provide an estimate of the total basin sediment yield for all storms in the given month (table 4). To estimate monthly storm-sediment yield at a given site, the mean SSC for all sampled storms was multiplied by the monthly total storm runoff volume and divided by the basin area.

\section{Storm-Sediment Yield}

Storm-sediment yield values are presented in table 2 . At Smith Branch (06928400), storm yields ranged from 1.12 to 232 pounds per square mile per minute $[(\mathrm{lb} / \mathrm{mi} 2) / \mathrm{min}]$ with a median basin yield of $16.8\left(\mathrm{lb} / \mathrm{mi}^{2}\right) / \mathrm{min}$. At Ballard Hollow tributary (06928410), storm yields ranged from 15.1 to $127\left(\mathrm{lb} / \mathrm{mi}^{2}\right) / \mathrm{min}$ with a median basin yield of $39.0(\mathrm{lb} / \mathrm{mi} 2) / \mathrm{min}$. Yields were not computed at Big Piney tributary (06930025) because SSCs were not believed to be representative of storm runoff, but more likely were the result of the release of water from the water-treatment sediment-settling ponds. At Quarry Hollow tributary (06930023), storm yields ranged from 0.405 to $41\left(\mathrm{lb} / \mathrm{mi}^{2}\right) /$ min with a median basin yield of $16.4\left(\mathrm{lb} / \mathrm{mi}^{2}\right) / \mathrm{min}$. At South ditch (374313092042401), the storm yields ranged from 0.240 to $372\left(\mathrm{lb} / \mathrm{mi}^{2}\right) / \mathrm{min}$ with a median basin yield of 5.09 (lb/mi2)/min. At Quarry Hollow tributary below quarry (06930027), the storm yields ranged from 0.584 to $26.5\left(\mathrm{lb} / \mathrm{mi}^{2}\right) / \mathrm{min}$ with a median basin yield of $5.22\left(\mathrm{lb} / \mathrm{mi}^{2}\right) / \mathrm{min}$. At Quarry Hollow tributary below quarry catchment (06930028), storm yields ranged from 1.24 to $7.43\left(\mathrm{lb} / \mathrm{mi}^{2}\right) / \mathrm{min}$ with a median basin yield of $2.85(\mathrm{lb} / \mathrm{mi} 2) / \mathrm{min}$. At East Gate Hollow tributary (06930058), storm yields ranged from 0.096 to $143\left(\mathrm{lb} / \mathrm{mi}^{2}\right) / \mathrm{min}$ with a median basin yield of $6.5\left(\mathrm{lb} / \mathrm{mi}^{2}\right) / \mathrm{min}$. At Dry Creek (06930250), storm yields ranged from 7.06 to $341\left(\mathrm{lb} / \mathrm{mi}^{2}\right) / \mathrm{min}$ with a median basin yield of $92.4\left(\mathrm{lb} / \mathrm{mi}^{2}\right) / \mathrm{min}$.

The storm-sediment yield is highly variable because of many factors that were not quantified during this study. Based on the median storm-sediment yield, for the storms sampled, Ballard Hollow tributary (06928410) and Dry Creek (06930250) contributed the greatest sediment mass per square mile, whereas South ditch (374313092042401), Quarry Hollow tributary (06930023), Quarry Hollow tributary below quarry (06930027), Quarry Hollow tributary below quarry catchment (06930028), and East Gate Hollow tributary (06930058) contributed the least sediment mass per square mile. Smith Branch (06928400) contributed an intermediate amount of sediment mass per square mile based on median storm-sediment yield.

\section{Monthly Storm-Sediment Yield}

Estimates of monthly storm-sediment yield (table 4) were computed for each streamgaged site, except for the Big Piney tributary (06930025), using equation 2, where the sampling duration (SAMPLE DURATION in equation 2) was 1 month. LOAD in equation 2 was estimated by computing the total storm discharge for the given month and multiplying that value by the mean SSC (converted to tons per cubic foot by multiplying by $3.1225 \times 10^{-8}$ ) for all samples collected at the given site.

Base flow discharge was not included in the computation of monthly total storm discharge. Base flow was assumed to be zero at the Smith Branch (06928400) and Dry Creek (06930250) sites. At East Gate Hollow tributary (06930058), high base flow was assumed to be $3.0 \mathrm{ft}^{3} / \mathrm{s}$ and was applied from the middle of May to the beginning of August, 2010, and from the middle of February to the middle of July 2011. Low base flow at the East Gate Hollow tributary (06930058) site was assumed to be $0.60 \mathrm{ft}^{3} / \mathrm{s}$ and was applied during the remainder of the period of record. Discharges below these two values were not included in the monthly totals during the periods stated. Discharge values that were greater than approximately $0.50 \mathrm{ft}^{3} / \mathrm{s}$ at the Quarry Hollow tributary below quarry (06930027) and Quarry Hollow tributary below quarry catchment (06930028) sites would likely indicate discharge derived from storm runoff. Because flow data were not being collected below $5.27 \mathrm{ft}^{3} / \mathrm{s}$ at Quarry Hollow tributary (06930023), computation of monthly total storm discharge from the downstream sites, Quarry Hollow tributary below 
Table 4. Estimated monthly storm-sediment yield (tons per square mile) in selected basins at the Fort Leonard Wood Military Reservation, Missouri.

$[--$, no data $]$

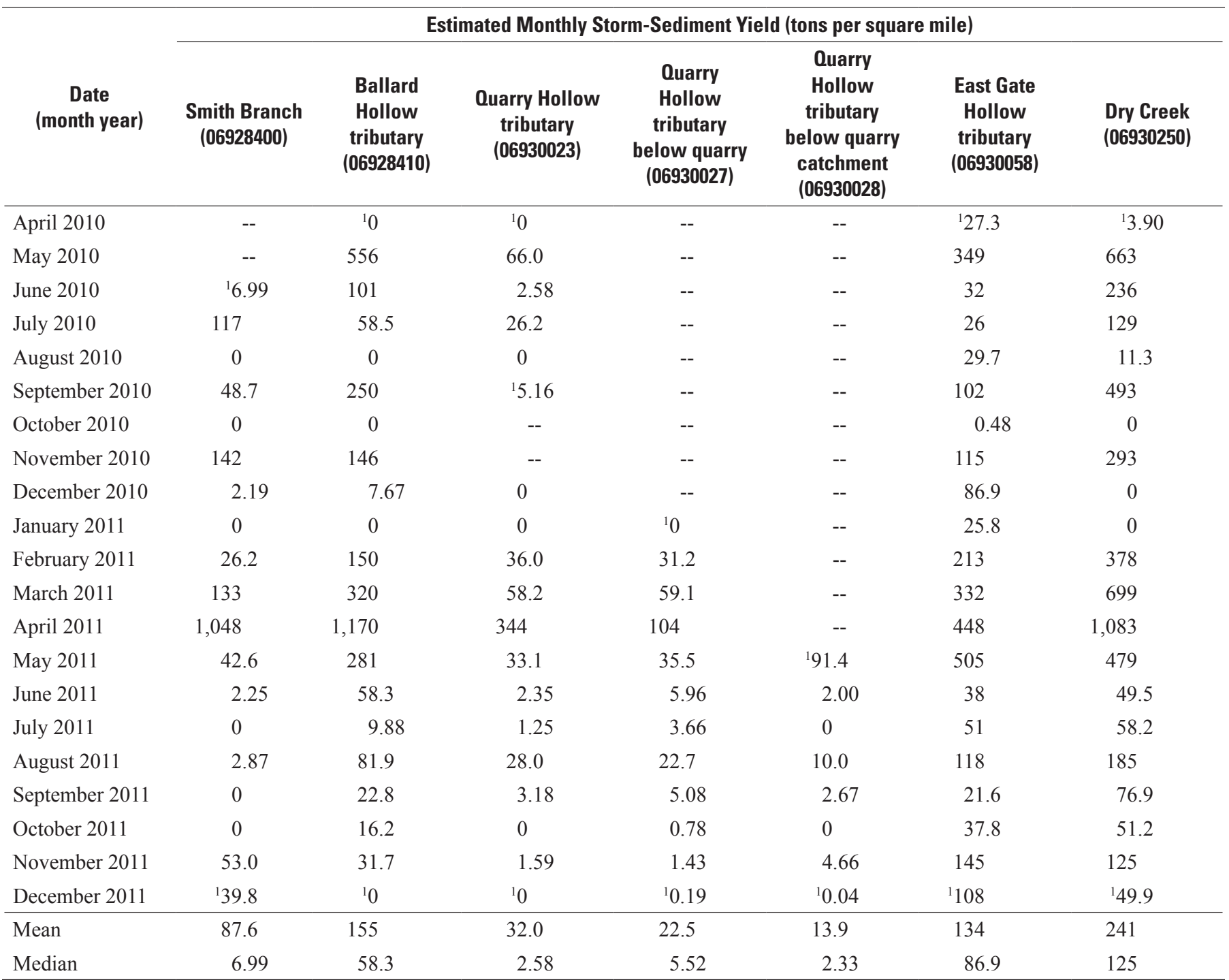

${ }^{1}$ Yield computed based on partial month discharge record.

quarry (06930027) and Quarry Hollow tributary below quarry catchment (06930028), did not include flow less than at $5.27 \mathrm{ft}^{3} / \mathrm{s}$ so the three sites could be compared. Because of the orifice elevation at the Ballard Hollow tributary (06928410) site, computation of monthly total storm discharge did not include flow less than $12.2 \mathrm{ft}^{3} / \mathrm{s}$.

The mean and median monthly storm-sediment yield estimates are presented in table 4 , and median yields were largest in Ballard Hollow tributary (06928410), East Gate Hollow tributary (06930058), and Dry Creek (06930250). The monthly storm-sediment yields at Ballard Hollow tributary (06928410), Quarry Hollow tributary (06930023), Quarry Hollow tributary below quarry (06930027), and Quarry Hollow tributary below quarry catchment (06930028) are likely being underestimated because the flow data less than $12.2 \mathrm{ft}^{3} / \mathrm{s}$ for site 06928410 and less than $5.27 \mathrm{ft}^{3} / \mathrm{s}$ for sites 06930023 , 06930027 , and 06930028 were not included in the calculations for those sites.

As would be expected, monthly yields tended to be larger during the wetter spring months and smaller during the drier summer months (table 4). For the period May to December 2011, when all streamgages were operating simultaneously, sediment yield from Ballard Hollow tributary (06928410), East Gate Hollow tributary (06930058), and Dry Creek (06930250) tended to have the largest estimated monthly yields. 


\section{Summary}

Commercial and residential development within a basin often increases the amount of impervious area, which changes the natural hydrologic response to storm events by increasing runoff. Increases in runoff lead to stream deformation, downcutting, and bank erosion, which results in excess sediment, a leading cause of water quality impairment throughout the United States. An increase in construction activities, caused by a population increase of more than 10 percent from 2000 to 2010 at the Fort Leonard Wood Military Reservation in Missouri, has potentially led to hydrologic changes that could result in the greater likelihood of stream impairment because of excess sediment. From April 2010 to December 2011, the U.S. Geological Survey, in cooperation with the U.S. Army Maneuver Support Center, collected surface-water hydrologic data during storm events in selected basins at the Fort Leonard Wood Military Reservation.

Hydrologic and suspended-sediment concentration data were collected primarily during storm events in six basins within the Fort Leonard Wood Military Reservation boundary. Hydrologic data collection included continuous and discrete discharge measurement data collected at nine sites and precipitation data collected at five sites. Sediment samples, collected at nine sites, primarily were collected using automatic samplers and augmented with equal-width-increment channel cross-sectional samples and manually collected samples when necessary. Sediment samples were analyzed for suspended-sediment concentration at the U.S. Geological Survey Missouri Water Science Center sediment laboratory. Storm-sediment load and yield were computed from discharge and suspended-sediment concentration data. Monthly stormsediment yields also were estimated from the total storm discharge and the mean suspended-sediment concentration at each given site.

Storm-sediment concentration, load, and yield varied from basin to basin and from storm to storm. In general, storm-sediment yield, in pounds per square mile per minute, was greatest from Ballard Hollow tributary (06928410) and Dry Creek (06930250), and monthly storm-sediment yield estimates, in tons per square mile, were largest in Ballard Hollow tributary (06928410), East Gate Hollow tributary (06930058), and Dry Creek (06930250).

\section{References Cited}

Buchanan, T.J., and Somers, W.P., 1974, Stage measurement at gaging stations: U.S. Geological Survey Techniques of Water-Resources Investigations, book 3, chap. A7, 27 p.

Edwards, T.K., and Glysson, G.D., 1999, Field methods for measurement of fluvial sediment: U.S. Geological Survey Techniques of Water-Resources Investigations, book 3, chap. C2, 89 p.

Fenneman, N.M., 1938, Physiography of the eastern United States: New York, McGraw-Hill, 714 p.

Guy, H.P., 1969, Laboratory theory and methods for sediment analysis: U.S. Geological Survey Techniques of WaterResources Investigations, book 5, chap. C1, 58 p.

Harrison, R.W., Orndorff, R.C., and Weems, Robert, 1996, Geology of the Fort Leonard Wood Military Reservation and adjacent areas of south-central Missouri: U.S. Geological Survey Open-File Report 96-60, 225 p., 10 pls.

Imes, J.L., Schumacher, J.G., and Kleeschulte, M.J., 1996, Geohydrologic and water-quality assessment of the Fort Leonard Wood Military Reservation, Missouri, 1994-95: U.S. Geological Survey Water-Resources Investigations Report 96-4270, 134 p.

Kennedy, E.J., 1984, Discharge ratings at gaging stations: U.S. Geological Survey Techniques of Water-Resources Investigations, book 3, chap. A10, 59 p.

Kennedy, E.J., 1989, Computation of continuous records of streamflow: U.S. Geological Survey Techniques of WaterResources Investigations, book 3, chap. A13, 53 p.

Kleeschulte, M.J., and Imes, J.L., 1997, Regional groundwater flow directions and spring recharge areas in and near the Fort Leonard Wood Military Reservation, Missouri: U.S. Geological Survey Fact Sheet 101-97, 4 p.

Lane, S.L., Flanagan, Sarah, and Wilde, F.D., 2003, Selection of equipment for water sampling-Version 2.0: U.S. Geological Survey Techniques of Water-Resources Investigations, book 9, chap. A2, 101 p., accessed March 26, 2012, at $h t t p: / / p u b s . w a t e r . u s g s . g o v / t w r i 9 A 2 /$. 
Mueller, D.S., and Wagner, C.R., 2009, Measuring discharge with acoustic Doppler current profilers from a moving boat: U.S. Geological Survey Techniques and Methods book 3, chap. A22, 72 p.

National Oceanic and Atmospheric Administration, n.d., Quality controlled local climatological data: accessed May 2012, at $h t t p: / / c d o . n c d c . n o a a . g o v / q c l c d / Q C L C D$ ? prior $=N$.

Sauer, V.B., 2002, Standards for the analysis and processing of surface-water data and information using electronic methods: U.S. Geological Survey Water-Resources Investigations Report 01-4044, 91 p.

Sturm, T.W., 2001, Open channel hydraulics: New York, McGraw-Hill, 493 p.

Turnipseed, D.P., and Sauer, V.B., 2010, Discharge measurements at gaging stations: U.S. Geological Survey Techniques and Methods book 3, chap. A8, 87 p.

U.S. Census Bureau, 2011, Fort Leonard Wood census-designated place (CDP) quickfacts from the U.S. Census Bureau: accessed July 2012, at http://quickfacts.census.gov/qfd/ states/29/2925264.html. 
Publishing support provided by: Rolla Publishing Service Center

For more information concerning this publication, contact: Director, USGS Missouri Water Science Center 1400 Independence Road

Rolla, M0 65401

(573) 308-3667

Or visit the Missouri Water Science Center Web site at: http://mo.water.usgs.gov/ 



